\title{
Dynamics and composition of the Asian summer monsoon anticyclone
}

\author{
Klaus-Dirk Gottschaldt ${ }^{1}$, Hans Schlager ${ }^{1}$, Robert Baumann ${ }^{1}$, Duy Sinh Cai ${ }^{1}$, Veronika Eyring ${ }^{1}$, Phoebe Graf ${ }^{1}$, \\ Volker Grewe $^{1,2}$, Patrick Jöckel ${ }^{1}$, Tina Jurkat-Witschas ${ }^{1}$, Christiane Voigt ${ }^{1,3}$, Andreas Zahn ${ }^{4}$, and Helmut Ziereis ${ }^{1}$ \\ ${ }^{1}$ Deutsches Zentrum für Luft- und Raumfahrt (DLR), Institut für Physik der Atmosphäre, Oberpfaffenhofen, Germany \\ ${ }^{2}$ Delft University of Technology, Aerospace Engineering, Delft, the Netherlands \\ ${ }^{3}$ Johannes Gutenberg-Universität, Institut für Physik der Atmosphäre, Mainz, Germany \\ ${ }^{4}$ Karlsruher Institut für Technologie (KIT), Institut für Meteorologie und Klimaforschung, Karlsruhe, Germany
}

Correspondence: Klaus-Dirk Gottschaldt (klaus-dirk.gottschaldt@dlr.de)

Received: 5 May 2017 - Discussion started: 23 June 2017

Revised: 2 March 2018 - Accepted: 15 March 2018 - Published: 24 April 2018

\begin{abstract}
This study places HALO research aircraft observations in the upper-tropospheric Asian summer monsoon anticyclone (ASMA) into the context of regional, intra-annual variability by hindcasts with the ECHAM/MESSy Atmospheric Chemistry (EMAC) model. The observations were obtained during the Earth System Model Validation (ESMVal) campaign in September 2012. Observed and simulated tracer-tracer relations reflect photochemical $\mathrm{O}_{3}$ production as well as in-mixing from the lower troposphere and the tropopause layer. The simulations demonstrate that tropospheric trace gas profiles in the monsoon season are distinct from those in the rest of the year, and the measurements reflect the main processes acting throughout the monsoon season. Net photochemical $\mathrm{O}_{3}$ production is significantly enhanced in the ASMA, where uplifted precursors meet increased $\mathrm{NO}_{x}$, mainly produced by lightning. An analysis of multiple monsoon seasons in the simulation shows that stratospherically influenced tropopause layer air is regularly entrained at the eastern ASMA flank and then transported in the southern fringe around the interior region. Radial transport barriers of the circulation are effectively overcome by subseasonal dynamical instabilities of the anticyclone, which occur quite frequently and are of paramount importance for the trace gas composition of the ASMA. Both the isentropic entrainment of $\mathrm{O}_{3}$-rich air and the photochemical conversion of uplifted $\mathrm{O}_{3}$-poor air tend to increase $\mathrm{O}_{3}$ in the ASMA outflow.
\end{abstract}

\section{Introduction}

The Asian monsoon system is one of the largest and most dominant atmospheric features on Earth. It is stronger than other monsoon systems because of the topography of the region, which insulates warm, moist air over South Asia (the sub-Himalayan countries of the Indian subcontinent) from the cold and dry extratropics (Boos and Kuang, 2010). This leads to a global maximum of surface moist static energy at the south-western flank of the Himalayas (Boos and Hurley, 2013), which drives deep convective updraughts during Northern Hemispheric summer. Elevated surface heating over the Tibetan plateau (Flohn, 1960; Fu et al., 2006), predominantly northward surface winds plus orographic uplifting at the southern/south-western slopes of the Himalayas ( $\mathrm{Li}$ et al., 2005; Y. Liu et al., 2009) and deep convection over the Bay of Bengal (Park et al., 2009; Nützel et al., 2016) all additionally contribute to an overall ascending air current. This drives an anticyclonic circulation, centred at 200 to $100 \mathrm{hPa}$ (Dunkerton, 1995; Randel and Park, 2006; Garny and Randel, 2016).

The location, shape and strength of the Asian summer monsoon anticyclone (ASMA) strongly vary on intraseasonal, interannual and longer timescales (Dunkerton, 1995; Lin et al., 2008; Kunze et al., 2010; Pokhrel et al., 2012), which is subject to ongoing discussion (Pan et al., 2016; Nützel et al., 2016). An elliptical vortex is intrinsically unstable (Hsu and Plumb, 2001; Popovic and Plumb, 2001), thus prone to splitting up and eddy shedding to the west and east (Dethof et al., 1999; Vogel et al., 2014). Vari- 
able forcing by convection (Randel and Park, 2006; Garny and Randel, 2013), subseasonal oscillations (Lin et al., 2008; Goswami, 2012), the interaction with Rossby waves or midlatitude synoptic disturbances (Dethof et al., 1999) add further complexity. The overall upwelling in the eastern ASM region is accompanied by large-scale subsidence in the western part (Rodwell and Hoskins, 1996), making the Arabian Peninsula one of the warmest and driest regions on Earth. The heat low associated with the hot desert conditions in summer produces an anticyclone (Lelieveld et al., 2009) in the middle to upper troposphere, which interacts with the ASMA.

The interplay of the above dynamical ingredients makes the Asian summer monsoon a switch yard and mixing vessel for air masses of different origins and with different compositions, including the exchange between the troposphere and stratosphere. Monsoon air is received by regions around the globe (Rauthe-Schöch et al., 2016) and was, for instance, shown to affect the tropospheric chemical composition in the Mediterranean (Lelieveld et al., 2001, 2002; Scheeren et al., 2003). A mid-tropospheric (400-500 hPa) summertime $\mathrm{O}_{3}$ maximum over the eastern Mediterranean/Middle Eastern region (Li et al., 2001; Lelieveld et al., 2009; Schuck et al., 2010; Akritidis et al., 2016) is enhanced by the Asian monsoon outflow (Y. Liu et al., 2009; Richards et al., 2013; Barret et al., 2016), but it is not clear whether $\mathrm{O}_{3}$ in the ASMA plume is generally enhanced or depleted (Lawrence and Lelieveld, 2010).

In the following TL refers to the mixing zone at the tropopause, where cross-tropopause exchange of air masses on average creates a gradient between stratospheric and tropospheric trace gas signatures. The TL is also denoted by ExTL in the extratropics and TTL in the tropics, reflecting the changes in dominating physical processes at about the $30^{\circ}$ in latitude. There are no rigid boundaries, but rather stratospheric influence decreases towards the troposphere over a range of several kilometres (Gettelman et al., 2011). In contrast, "upper troposphere" (UT) is used here to describe the altitude region that is dominated by the ASMA. Despite its importance for redistributing trace gases between the boundary layer, troposphere and lower stratosphere, the highly variable composition of the ASMA and the processes behind it are not well understood yet (Randel et al., 2016).

In situ measurements were conducted in the ASMA during the Earth System Model Validation (ESMVal) field experiment with the High Altitude and LOng Range (HALO) research aircraft in September 2012. A sudden enhancement of measured $\mathrm{O}_{3}$ when HALO entered the ASMA from the south was the motivation for the accompanying paper (Gottschaldt et al., 2017), since those measurements contrast with the presumption of decreased $\mathrm{O}_{3}$ in the ASMA. It was shown that the ASMA filament(s) encountered during that flight were associated with entrainments of lower-/mid-tropospheric air at the eastern ASMA flank as well as with stratospherically influenced TL air.
Here we put the specific situation observed during the HALO ESMVal campaign into a regional, seasonal and multi-annual perspective, which is provided by global chemistry climate simulations with the ECHAM/MESSy Atmospheric Chemistry (EMAC) model.

Recent papers discussed climatological trace gas distributions in the monsoon region (Santee et al., 2017), CO distributions in the context of daily ASMA dynamics (Pan et al., 2016) and monthly budgets of $\mathrm{CO}$ and $\mathrm{O}_{3}$ (Barret et al., 2016). Building on the ASMA observations during the HALO ESMVal campaign, the second objective of our study is to complement these papers by considering additional tracers on a 10-hourly scale to characterise key processes relevant for the $\mathrm{O}_{3}$ distribution in the monsoon region.

We first briefly summarise the data used here, then discuss the EMAC-simulated intra-annual variability of selected tracers in the ASMA region for the year of the HALO ESMVal campaign, put observed tracer-tracer relations in the context of simulated ones, discuss the interplay of the processes that contributed to the observed trace gas signatures and also show in the context of multiple monsoon seasons that the specific situation observed during the HALO ESMVal campaign was not exceptional. For brevity the main text only provides summarising statements about lightning $\mathrm{NO}_{x}\left(\mathrm{LiNO}_{x}\right)$ and reactive nitrogen $\left(\mathrm{NO}_{y}\right)$ in the ASMA, and we refer to the Supplement for details. Additional figures in the Supplement are provided for documentation and reproducibility.

\section{Data}

We focus on the analyses of $\mathrm{O}_{3}, \mathrm{CO}$, hydrogen chloride $(\mathrm{HCl})$ and reactive nitrogen $\left(\mathrm{NO}, \mathrm{NO}_{x}, \mathrm{NO}_{y}\right)$, as those tracers reflect the processes most relevant for the interpretation of in situ measurements in the ASMA during the ESMVal flight from Male (Maldives) to Larnaca (Cyprus) on 18 September 2012. All in situ measurements used here are based on a data set with a $10 \mathrm{~s}$ time resolution, which is available from the HALO database (https://halo-db.pa.op.dlr.de). The corresponding measurement techniques are described in the accompanying paper and in more detail in publications about the individual instruments: $\mathrm{CO}$ (Hoor et al., 2004; Schiller et al., 2008; Müller et al., 2016), HCl (Jurkat et al., 2014; Voigt et al., 2014), NO/NO (Ziereis et al., 2000) and $\mathrm{O}_{3}$ (Zahn et al., 2012). Among those tracers, only $\mathrm{HCl}$ mixing ratios were at the instrument's detection limit during the considered flight (Jurkat et al., 2016).

The transport pathways of air parcels before being encountered by HALO were calculated with the Lagrangian HYSPLIT model (Draxler and Hess, 1998; Draxler and Rolph, 2015). Although published in the accompanying paper, those analyses are a basis for this study. 


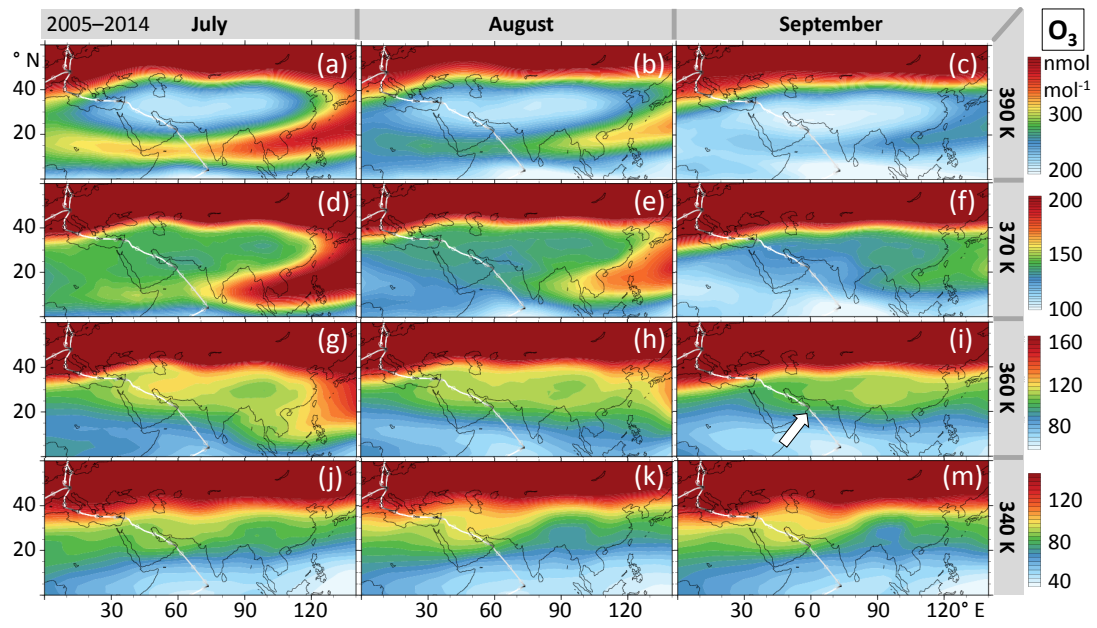

Figure 1. EMAC-simulated $\mathrm{O}_{3}$ at different isentropic surfaces. Multi-annual monthly averages are calculated for the same period as in Santee et al. (2017) and agree well with their figures ( 370 and $390 \mathrm{~K}$ ). However, at the level corresponding to the HALO flight altitude ( $360 \mathrm{~K})$, $\mathrm{O}_{3}$ is enhanced in the ASMA in September (i) and the observed sudden increase at the southern ASMA edge over Oman is also reproduced (arrow).

In the following all simulation data stem from global chemistry climate simulations with the EMAC model (Jöckel et al., 2010), performed within the ESCiMo (Earth System Chemistry integrated Modelling) project (Jöckel et al., 2016) and the DLR-internal ESMVal project. Our reference simulation has been described and generally evaluated as RC1SDbase-10a by Jöckel et al. (2016). Its set-up is designed for the best possible comparability to observations by nudging the dynamics to ECMWF ERA-Interim (Dee et al., 2011) reanalysis data and covers the period 1980-2013 (excluding spin-up). Convection is not resolved in the simulation, but its effects are captured by a parameterisation in EMAC. $\mathrm{LiNO}_{x}$ emissions are parameterised on top of the convection parameterisation. Given the above uncertainties, simulated lightning activity compares acceptably with satellite observations (Supplement).

$\mathrm{NO}_{x}$ background mixing ratios are crucial for $\mathrm{O}_{3}$ photochemistry, as will be discussed in more detail in Sect. 6.3. In situ measurements are the most accurate in the UT. We have shown in the accompanying paper that this simulation reproduces the measured trace gas mixing ratios along the HALO flight track of 18 September 2012 reasonably well, but this comparison is rather limited, spatially and temporally. Therefore we compare simulated $\mathrm{NO}$ and $\mathrm{NO}_{y}$ to one of the most comprehensive observational data sets available for reactive nitrogen in the UT (Stratmann et al., 2016): IAGOSCARIBIC (In-service Aircraft for a Global Observing System - Civil Aircraft for the Regular Investigation of the atmosphere Based on an Instrument Container; Brenninkmeijer et al., 2007, http://www.caribic-atmospheric.com). Our comparisons are based on the output of the EMAC S4D submodel (Jöckel et al., 2010), which provides simulation data along the given IAGOS-CARIBIC flight tracks at each model time step ( $\Delta t=12 \mathrm{~min}$ ). The agreement between simulated $\mathrm{NO}$ and corresponding IAGOS-CARIBIC observations is remarkable, particularly in the ASMA region (Supplement). Further comparisons between the EMAC RC1SD-base-10a simulation and IAGOS-CARIBIC are shown by Jöckel et al. (2016) for $\mathrm{O}_{3}, \mathrm{CO}$ and others, based on 10-hourly simulation output.

Ten-year averages of simulated $\mathrm{O}_{3}$ reproduce the low- $\mathrm{O}_{3}$ ASMA interior of satellite climatologies (Santee et al., 2017) as well as increased $\mathrm{O}_{3}$ found by HALO ESMVal at slightly lower potential temperatures (Fig. 1).

Additional EMAC simulations were performed in quasichemistry transport model mode (Deckert et al., 2011; Gottschaldt et al., 2013) to test the impact of $\mathrm{LiNO}_{x}$. These are described in the Supplement. "Simulation" without further specification refers to RC1SD-base-10a in the following.

\section{The ASMA region}

As noted in the introduction, the ASMA is driven by a largescale updraught originating from the south-western flank of the Himalayas, on the one hand, and by smaller-scale tropical deep convection events, on the other hand. The latter correlates with a maximum of outgoing long-wave radiation (OLR), which expands from the Bay of Bengal towards the Tibetan plateau and back in the course of the monsoon season (Nützel et al., 2016). In contrast, the large-scale updraught is tied to geographical features (maximum of moist static energy in the Indo-Gangetic plain, heating of the Tibetan plateau, orographic forcing of the Himalayas). The inland thermodynamic conditions of the Arabian Peninsula support the mid-tropospheric anticyclone in the west. It may intermittently merge with the ASMA, but we presume that the 


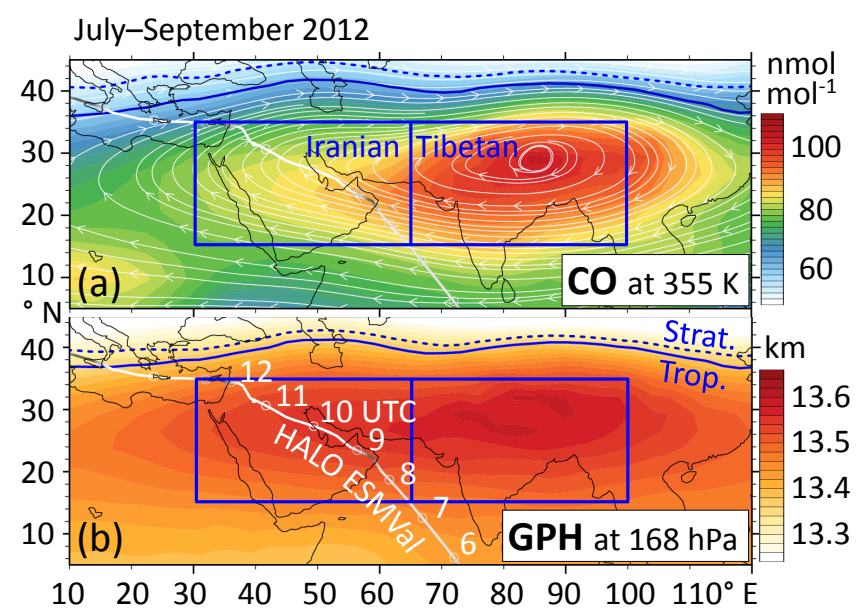

Figure 2. CO mixing ratios and geopotential height (GPH) simulated by EMAC for the monsoon months of 2012. Enhanced CO is considered to be a chemical characteristic of the ASMA, and increased GPH is a dynamical proxy used to delimit the ASMA. The Iranian and Tibetan domains are used throughout the paper to discuss differences between the convectively driven eastern part and the western part that is mainly controlled by UT transport. The Iranian region was traversed by the HALO ESMVal campaign during a flight from Male (Maldives) to Larnaca (Cyprus) on 18 September 2012. Beads show the HALO positions at full UTC hours, and the chosen isentropic (a) or pressure (b) levels roughly correspond to UT flight sections.

composition of the UT in the west is determined mainly by air transported in the eastern-driven circulation. We refer to the western and eastern parts as "Iranian" and "Tibetan", respectively. ASMA unspecifically refers to the whole system.

The regions' delimitations (Fig. 2) for separate analyses of the different parts were chosen visually, considering the following: (i) to put the measurements into perspective, the regions shall capture the synoptic situation during the HALO ESMVal campaign; (ii) both parts shall be equally sized; (iii) the variability of the ASMA's location and extent shall be covered. The chosen meridional range of 15 to $35^{\circ} \mathrm{N}$ covers the simulated ASMA ridgeline for most of the monsoon season (shown in Fig. 3b). The zonal ranges are 30 to 65 and 65 to $100^{\circ} \mathrm{E}$ for the Iranian and Tibetan regions, respectively. For comparison, Yan et al. (2011) classified anticyclonic centres between 50 and $67.5^{\circ} \mathrm{E}$ in Iranian mode, and between 80 and $92.5^{\circ} \mathrm{E}$ in Tibetan mode.

We decided not to adapt the regions dynamically to the actual ASMA, because the boundary definitions we are aware of (Ploeger et al., 2015; Barret et al., 2016; Pan et al., 2016) emphasise the concept of a closed ASMA volume or transport barriers on monthly or seasonal timescales. However, the ASMA boundaries are not always well defined, particularly during transitions between different dynamical modes. Our pre-fixed regions allow an unbiased view on the effects of complex, 10-hourly dynamics. This comes at the price that features from outside the ASMA might contribute to the analyses occasionally. We cannot rule out that concurrent but geographically distinct features feign correlations between different species, but monsoon-related features should mostly dominate the lateral averages in the chosen regions. Our approach detects differences between Iranian and Tibetan parts, because the corresponding circulation is tied to the geographical features of these regions. Enhanced CO is considered to be a chemical characteristic of the ASMA (Pan et al., 2016), and increased geopotential height (GPH) is a dynamical proxy (Barret et al., 2016). Simulated seasonal mean distributions of both proxies indicate that our regions capture the ASMA of 2012 well (Fig. 2).

Large-scale transport occurs mainly on isentropes, unlike convective transport. Pressure and isentropic vertical coordinates are similar in the UTLS in the tropics of the Tibetan region (Fig. 4a). In the EMAC simulation the TP has been diagnosed by a potential vorticity of $3.5 \mathrm{PVU}$ in the extratropics and by the WMO definition between $30^{\circ} \mathrm{N}$ and $30^{\circ} \mathrm{S}$ (Jöckel et al., 2006). It is almost parallel to one isentrope in the tropics and to a lower one in the extratropics, but intersects isentropes around $360 \mathrm{~K}$ almost perpendicularly in the transition region at about $30^{\circ} \mathrm{N}$. This facilitates isentropic in-mixing from the lower stratosphere or the TL, but only in combination with southward wind components. If winds follow the TP (e.g. subtropical jet), it is still a transport barrier. The latter aspect is relevant for stratosphere-to-troposphere trace gas gradients and is captured by coordinates relative to the TP (used for Figs. 5-7). The barrier effect of the TP is also relevant for convective transport (TP following coordinates also used for Fig. 7). Isentropic coordinates account for the seasonal evolution of potential temperature $(\theta$, Fig. 4b) and best capture isentropic transport (used for Fig. 3, but also for the supplementary 5-year equivalents to Figs. 5-7).

\section{Tracer-tracer relations in September 2012}

The distribution of points in a tracer-tracer diagram provides hints on the origin and evolution of air masses. A short primer for the interpretation of such diagrams is provided in the Supplement.

\subsection{Selected tracers}

Here we focus on $\mathrm{CO}$ versus $\mathrm{O}_{3}$ and $\mathrm{HCl}$ versus $\mathrm{O}_{3}$ (Fig. 8) as well as on $\mathrm{NO}_{x}$ versus $\mathrm{O}_{3}$ and $\mathrm{NO}_{x}$ versus $\mathrm{NO}_{y}$ (Fig. 9).

$\mathrm{O}_{3}$ mixing ratios in the TL exhibit a strong vertical gradient, increasing from the troposphere to the stratosphere. Given a chemical lifetime of the order of weeks, this reflects the degree of mixing between $\mathrm{O}_{3}$-poor UT air and $\mathrm{O}_{3}$ rich air from the lowermost stratosphere (Sprung and Zahn, 2010). That general picture might not hold in the ASMA though, where - depending on the availability of precursors - 


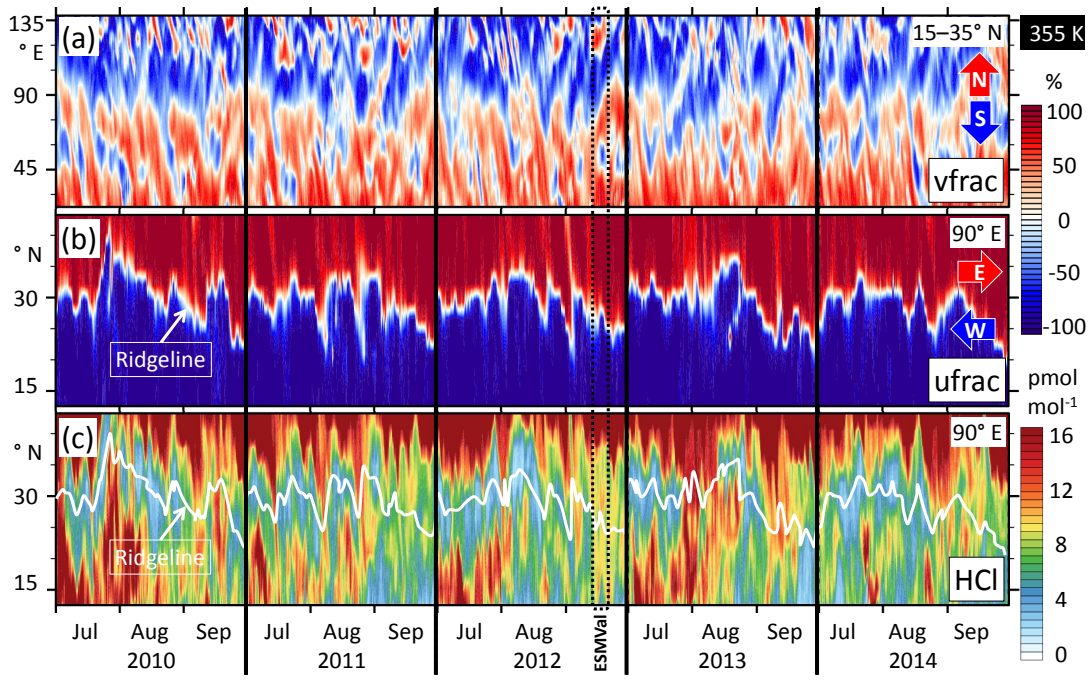

Figure 3. Exploratory analyses of the frequency of occurrence of (i) dynamical instabilities of the ASMA and (ii) transport of TL air in the free troposphere along the southern ASMA fringe. All panels show 10-hourly EMAC simulation results at the $355 \mathrm{~K}$ isentropic level, for the summer monsoon months in the ASMA region. (a) Meridional wind fraction (calculated as $v / \sqrt{u^{2}+v^{2}}$, with meridional velocity $v$ and zonal velocity $u$ ) along a wide zonal transect, averaged with dry grid-cell mass weighting at each longitude from 15 to $35^{\circ} \mathrm{N}$. Blue shades indicate southward and red shades northward winds. Each red-blue pair (from west to east) at a given time marks an anticyclone or a smaller eddy. (b) As in panel (a), but for zonal wind fraction $\left(u / \sqrt{u^{2}+v^{2}}\right)$ along a meridional transect at $90^{\circ}$ E. Blue shades indicate westward and red indicates eastward winds. (c) Time evolution of $\mathrm{HCl}$ mixing ratios. At any given time, locally increased $\mathrm{HCl}$ south of the ridgeline is a proxy for air from the TL or the stratosphere.

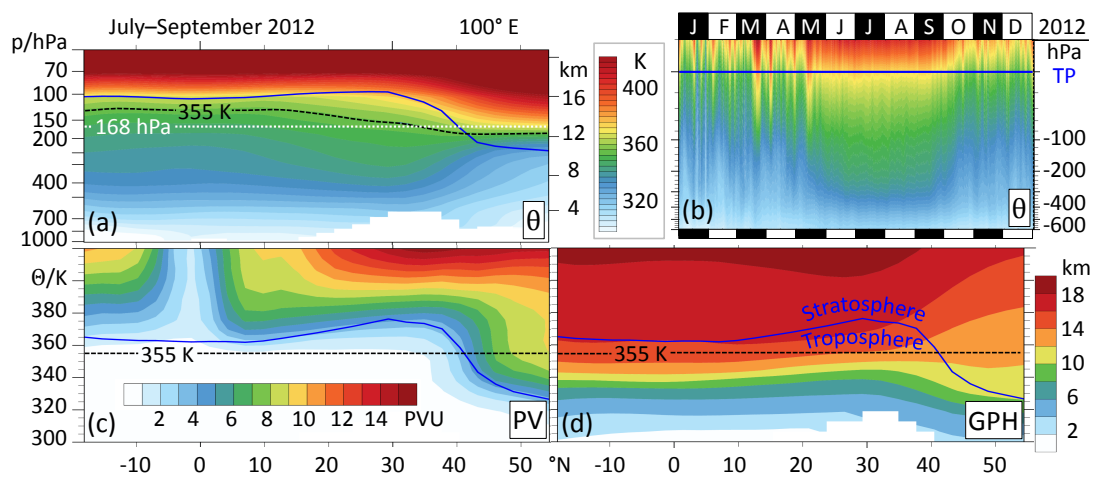

Figure 4. EMAC-simulated relations between different parameters of the stratification of the atmosphere in the Tibetan region. Potential temperature $(\theta)$, potential vorticity $(\mathrm{PV})$ and geopotential height $(\mathrm{GPH})$ in vertical cross sections at $100^{\circ} \mathrm{E}$. The levels of $\theta=355 \mathrm{~K}$ and $p=168 \mathrm{hPa}$ are chosen for horizontal slices in the paper. Panels (a), (c), (d) show time averages for the monsoon months of 2012. Panel (b) shows the evolution of $\theta$ profiles (grid-cell dry air mass weighted averages from $15-35^{\circ} \mathrm{N}, 65-100^{\circ} \mathrm{E}$ ) throughout 2012 in pressure coordinates relative to the tropopause (TP). Note the steeply inclining TP over the Tibetan plateau, which marks the transition from the extratropics (dominated by baroclinic wave activity and downward stratospheric circulation) to the tropics (dominated by radiative-convective balance and upward stratospheric circulation). Heating of the Tibetan plateau in summer brings UT isentropes closer to the surface (panel b), leading to intersections between the inclined TP and a range of isentropes (panel a).

enhanced photochemical $\mathrm{O}_{3}$ production is superimposed on isentropic in-mixing from the stratosphere.

Enhanced $\mathrm{CO}$ is a tracer of boundary layer pollution and an $\mathrm{O}_{3}$ precursor in the troposphere. Oxidation with the hydroxyl radical $(\mathrm{OH})$ prevails under stratospheric conditions, and $\mathrm{CO}$ mixing ratios decrease by about an order of magnitude across the tropopause (Hoor et al., 2002).
As a tracer for stratospheric air we use $\mathrm{HCl}$ (Marcy et al., 2004; Park et al., 2008), which in the UT has no significant photochemical sources but has a lifetime similar to $\mathrm{O}_{3}$. Wet scavenging in clouds effectively prevents convective transport of $\mathrm{HCl}$ to the $\mathrm{UT}$, and no injections of $\mathrm{HCl}$ from volcanic activity affected the ESMVal flight from Male to Larnaca. Together this makes $\mathrm{HCl}$ a viable tracer of stratospheric $\mathrm{O}_{3}$ 


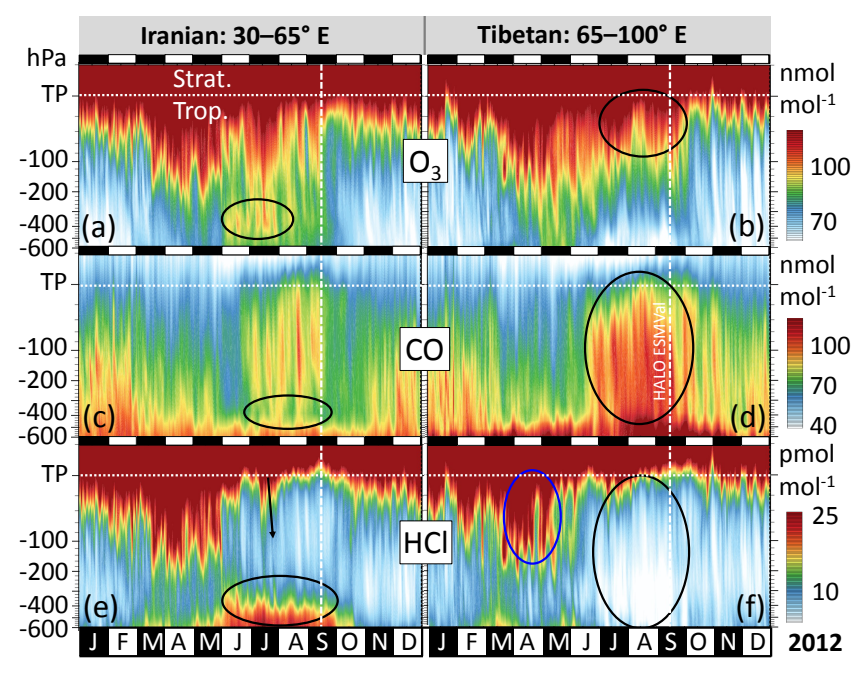

Figure 5. Evolution of simulated trace gas profiles in the western and eastern ASMA regions throughout 2012. The time of the HALO ESMVal measurements is indicated by a dashed line. Vertical coordinates are given as pressure distance to the tropopause (TP), whose altitude depends on time and location. All values are grid-cell dry air mass weighted averages from 15 to $35^{\circ} \mathrm{N}$ (see Fig. 2). Marked features are discussed in the text.

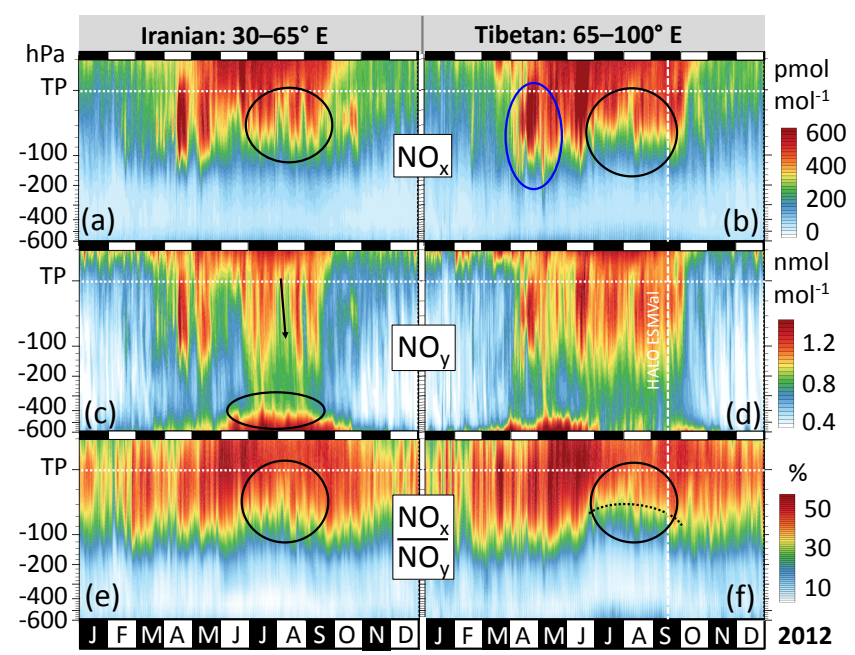

Figure 6. As in Fig. 5, but focusing on reactive nitrogen. Examples of individual profiles from panels (c) and (d) are given in the Supplement.

entrainments, until it is selectively removed by wet scavenging.

$\mathrm{NO}_{x}\left(\mathrm{NO}+\mathrm{NO}_{2}\right)$ is an $\mathrm{O}_{3}$ precursor and part of $\mathrm{NO}_{y}$. $\mathrm{NO}_{x}$ primarily characterises fresh emissions. Only NO was measured during the HALO ESMVal campaign, but daytime $\mathrm{NO}$ is a good proxy for $\mathrm{NO}_{x}$ in the UT (Seinfeld and Pandis, 2006). In the UTLS, enhanced $\mathrm{NO}_{y}$ originates both from tropospheric and stratospheric sources. Thus it is not a viable tracer for stratospheric air on its own. In the lower tro-

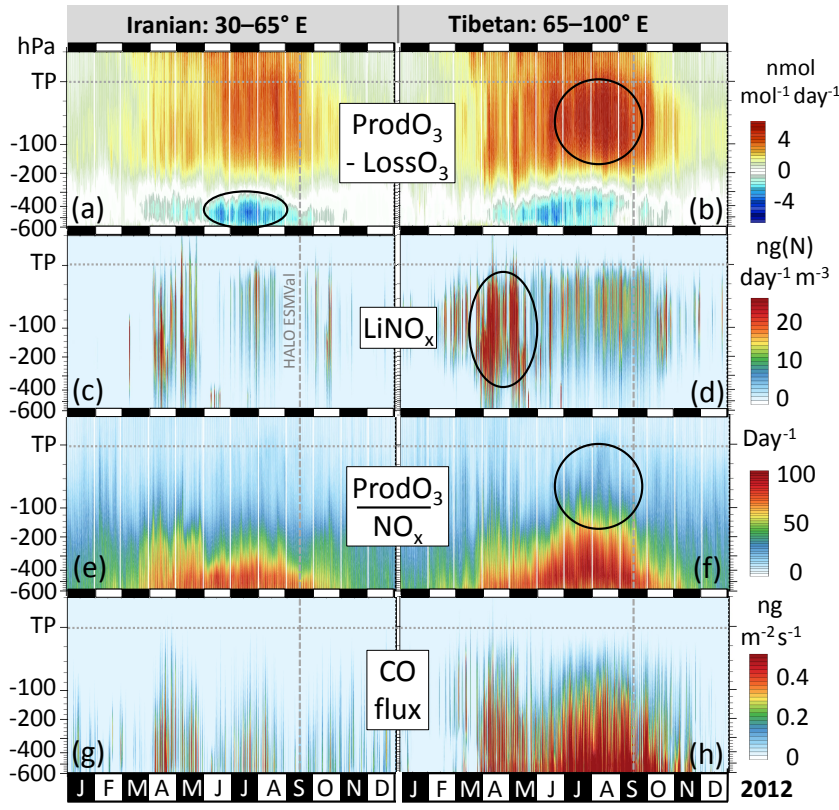

Figure 7. As in Fig. 5, but for different parameters related to net photochemical $\mathrm{O}_{3}$ production $\left(\mathrm{ProdO}_{3}-\mathrm{LossO}_{3}\right)$. Lightning $\mathrm{NO}_{x}$ $\left(\mathrm{LiNO}_{x}\right)$ emissions in the model are determined by parameterisations for convection, lightning and $\mathrm{NO}_{x}$ emissions per flash. $\mathrm{CO}$ flux reflects the concurrence of deep convective mass flux and $\mathrm{CO}$ mixing ratio, but as a simple product neither account for entrainment and detrainment of convection. Panels (e) and (f) highlight the non-linear dependence of $\mathrm{O}_{3}$ production on $\mathrm{NO}_{x}$ mixing ratios. Strong gradients indicate the transition between $\mathrm{NO}_{x}$-limited and $\mathrm{NO}_{x}$-saturated photochemical regimes, but are superimposed by the effects of other $\mathrm{O}_{3}$ precursors. Individual profiles from panels (a) and (b) are shown in the Supplement.

posphere odd nitrogen species are co-emitted with carbon monoxide in combustion processes. Lightning and aircraft emissions are sources in the UT. Photolysis of $\mathrm{N}_{2} \mathrm{O}$ peaks at about $30 \mathrm{~km}$ and is the principal source of $\mathrm{NO}_{x}$ in the stratosphere, resulting in increasing mixing ratios of $\mathrm{NO}_{x}$ and $\mathrm{NO}_{y}$ above the TP (Seinfeld and Pandis, 2006).

\subsection{Ranges covered by observed and simulated tracer-tracer distributions}

In order to place the observed tracer-tracer relations into context, we plot the measured samples together with gridcell samples from the EMAC simulation. Simulation output along the flight track is too sparse for a meaningful comparison (10 s resolution of measurements versus $12 \mathrm{~min}$ for the simulation). Therefore 5000 simulated samples per panel are chosen randomly, from the entire month of September 2012 and from throughout the ASMA region (Fig. 2: Tibetan and Iranian parts). Plotting all corresponding samples from the EMAC simulation would impair the visibility of clustering. Two different vertical ranges are chosen. The range from 


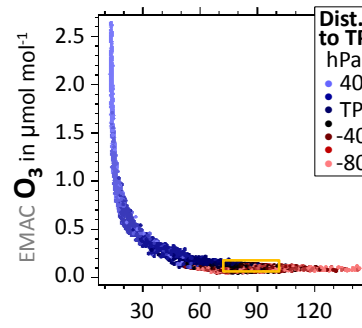

(a)
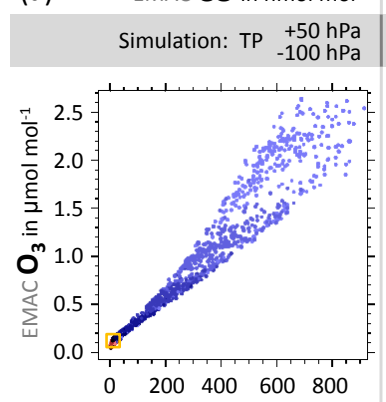

(d) $\mathrm{EMAC} \mathbf{H C l}$ in $\mathrm{pmol} \mathrm{mol}^{-1}$

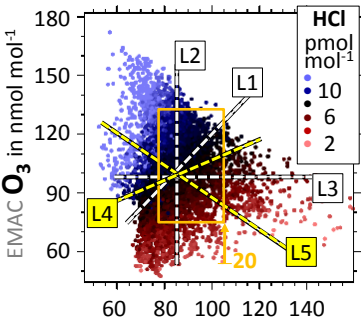

(b)

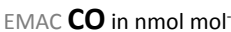

Simulation: $200-100 \mathrm{hPa}$

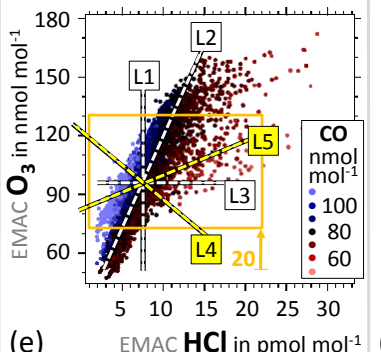

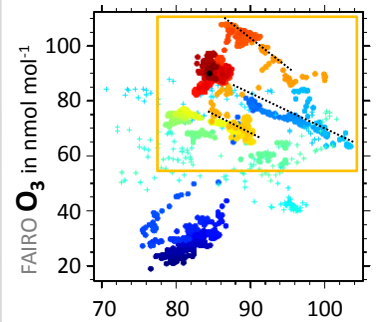

(c)

Observations

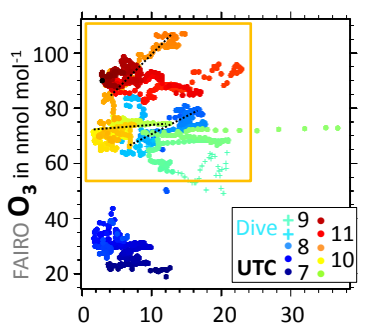

(f)

AIMS $\mathbf{H C l}$ in pmol mol-1

Figure 8. Tracer-tracer relations simulated by EMAC for the whole of September 2012 in the ASMA region and observed by HALO during the HALO ESMVal campaign on 18 September 2012. (a, d) Simulated samples from the region $15-35^{\circ}$ N, $30-100^{\circ}$ E. Colour coding corresponds to the pressure distance to the tropopause, from $100 \mathrm{hPa}$ below to $50 \mathrm{hPa}$ above. (b, e) Simulated tracer mixing ratios from the same region, but limited to tropospheric cells in the pressure altitude range $200-100 \mathrm{hPa}$. Colour coding indicates corresponding mixing ratios of $\mathrm{HCl}$. See text for details of hypothetic lines L1-L5. (c, f) Observed tracer mixing ratios of the HALO flight from Male to Larnaca (without initial and final stages). Colours correspond to the UTC time of measurement, also indicating spatial proximity. The orange boxes show the ranges covered by the measurements from within the ASMA.
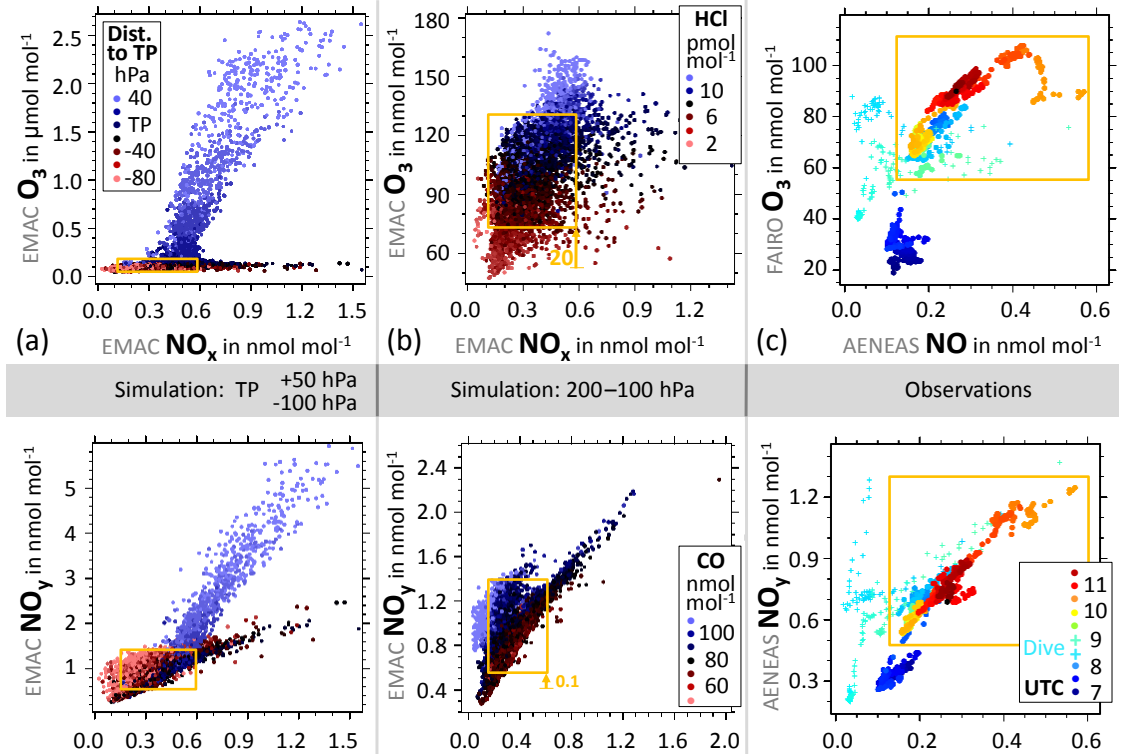

(c) AENEAS NO in $\mathrm{nmol} \mathrm{mol}^{-1}$
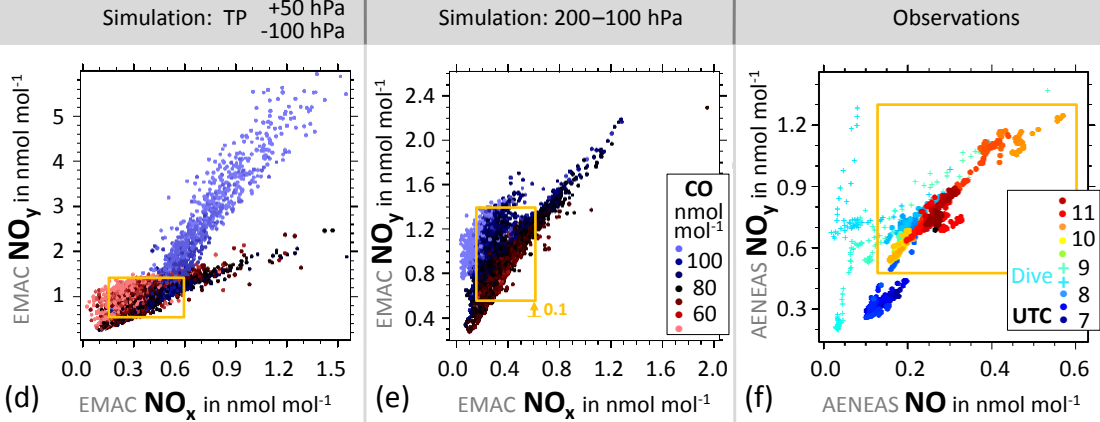

Figure 9. As in Fig. 8, but focusing on reactive nitrogen. Panels (c) and (f) show NO instead of $\mathrm{NO}_{\mathbf{x}}$, because only NO was measured. In the daytime, i.e. at the time of the measurements, $\mathrm{NO}$ is good proxy for $\mathrm{NO}_{x}$. The legend from panel (a) also applies to (d), and the legend from (f) applies to (c). 
50 above the TP to $100 \mathrm{hPa}$ below it in the actual EMAC tropopause (Fig. 8a, d) provides a zoomed-out view of possible tropospheric and stratospheric tracer mixing ratios and tracer-tracer relations for the time of year and region of the measurements. Zooming-in to the altitude range of measurements, we choose tropospheric tracers from the pressure altitude range 200 to $100 \mathrm{hPa}$ (Fig. $8 \mathrm{~b}$, e). The observations from the entire flight without ascent and descent are shown in (Fig. 8c, f).

Measurements south of the ASMA are marked by darkblue dots in Fig. 8c, f and are clearly distinct from the measurements in the ASMA filament (orange boxes). The ranges covered by the measurements are also given in the corresponding panels with simulated data, but are adjusted for model biases there. Those biases were estimated according to visual comparisons of measured versus simulated trace gas mixing ratios along the flight track in the ASMA filament (shown in the accompanying paper). All measured ranges fit into the simulated monthly averages for September 2012 in the ASMA region; thus the simulation captures this aspect well and the measurements are unlikely to represent an exceptional situation. We also note that all measurements clearly fall into the tropospheric regions of the respective simulated tracer-tracer spaces. This is no surprise: all HALO ESMVal measurements considered here were taken well within the troposphere.

Simulated $\mathrm{O}_{3}$ and $\mathrm{NO}_{x}$ increase in the stratosphere with a higher $\mathrm{O}_{3} / \mathrm{NO}_{x}$ ratio than in the troposphere (Fig. 9a). However, since the range covered by the HALO ESMVal measurements is just at the intersection of the stratospheric and tropospheric branches (orange box in Fig. 9a), this does not help to distinguish the stratospheric influence from tropospheric in situ production.

\subsection{In situ photochemistry, tropospheric and TL contributions}

The colour code of the observations (Fig. 8c, f) corresponds to measurement time. Similar colours indicate spatial and temporal proximity, a prerequisite for mixing lines. Schematic lines L1-L5 (Fig. 8b, e) and their parallels indicate special, hypothetical cases for the evolution of air masses, which are discussed next.

\subsection{1 $\mathrm{CO}$ versus $\mathrm{O}_{3}$ (Fig. 8a-c)}

$\mathrm{O}_{3}$ and $\mathrm{CO}$ display opposite gradients across the tropopause and globally have lifetimes of several months in the UT (IPCC, 2013). Thus mixing lines in a $\mathrm{CO}$ versus $\mathrm{O}_{3}$ scatter plot are generally suited to identifying stirring and mixing processes in the UT that occur on timescales of days to weeks, including cross-tropopause mixing (Fischer et al., 2000). The well-known L-shape (Hoor et al., 2002; Pan et al., 2004; Müller et al., 2016) is reproduced by the simulation in the $\mathrm{CO}$ vs. $\mathrm{O}_{3}$ diagram for the UTLS (Fig. 8a), consisting of a CO-poor and $\mathrm{O}_{3}$-rich stratospheric branch connected by UTLS mixing lines to a $\mathrm{CO}$-rich and $\mathrm{O}_{3}$-poor tropospheric branch.

However, the above studies (Hoor et al., 2002; Pan et al., 2004; Müller et al., 2016) focused on the extratropics. The ASMA is mostly situated in the tropics, where trace gas mixing ratios are controlled by different processes (Gettelman et al., 2011). The ASMA in particular constitutes a special atmospheric situation, because a continuous resupply of rapidly uplifted lower-tropospheric air impedes the UT photochemical equilibrium there. $\mathrm{O}_{3}$ is photochemically produced in the ASMA at a net rate of almost $4 \mathrm{nmol} \mathrm{mol}^{-1}$ day $^{-1}$ (Barret et al., 2016; and Fig. 7b, which will be discussed in Sect. 6). Only 2 weeks are needed to increase $\mathrm{O}_{3}$ mixing ratios by $50 \mathrm{nmol} \mathrm{mol}^{-1}$, i.e. to produce the $\mathrm{O}_{3}$ enhancement observed at the southern ASMA edge. This is not much longer than the advection timescale ( $\sim 10$ days) discussed in the context of the HALO ESMVal campaign. Thus photochemical production needs to be considered an alternative to stratospheric in-mixing to explain enhanced $\mathrm{O}_{3}$ in the ASMA. Photochemical ageing increases $\mathrm{O}_{3}$ and depletes $\mathrm{CO}$ here.

Mixing lines with negative slopes in $\mathrm{CO}$ vs. $\mathrm{O}_{3}$ space dominate the UT observations (black dotted in Fig. 8c). These types of mixing lines in the troposphere could result from one or a combination of the following: (i) mixing between stratospherically and tropospherically influenced air masses, (ii) mixing between photochemically aged and freshly uplifted lower-tropospheric air and (iii) an $\mathrm{O}_{3}$-depleting photochemical regime (Baker et al., 2011). While the latter is unlikely in the ASMA (Fig. 7b), we need to consider additional tracers to disentangle stratospheric influence and photochemical ageing.

\subsection{2 $\mathrm{HCl}$ versus $\mathrm{O}_{3}$ (Fig. 8d-f)}

$\mathrm{HCl}$ is a proxy for stratospheric entrainment and $\mathrm{CO}$ marks tropospheric influence. Consider the hypothetical case of constant $\mathrm{HCl}$ (lines L1 and parallels in Fig. 8b, e): increasing $\mathrm{O}_{3}$ corresponds to increasing $\mathrm{CO}$. The trace gas gradients along that hypothetical line reflect a gradient in net $\mathrm{O}_{3}$ production rather than differences with respect to stratospheric influence between the two reservoirs. Now consider the opposite case, i.e. constant $\mathrm{CO}$ (lines L2): increasing $\mathrm{O}_{3}$ corresponds to increasing $\mathrm{HCl}$, indicating a gradient of stratospheric influence. $\mathrm{CO}$ mixing ratios decrease for increasing $\mathrm{HCl}$ in the special case of constant $\mathrm{O}_{3}$ and different $\mathrm{HCl}$ mixing ratios (lines L3). This indicates mixing between a tropospheric and a stratospheric reservoir, where two opposite effects lead to almost constant $\mathrm{O}_{3}$ mixing ratios: increased net $\mathrm{O}_{3}$ production in the air with decreased $\mathrm{HCl}$ versus both increased $\mathrm{O}_{3}$ and $\mathrm{HCl}$ in the more stratospheric components. In intermediate cases the trace gas gradients in the tracer-tracer plots reflect a combination of gradients of in-mixing as well as in situ photochemistry. Spatial gradients of photochemical 
$\mathrm{O}_{3}$ production dominate over gradients of stratospheric influence (i.e. in-mixing from the TL or stratosphere) within the sampled air mass if increasing $\mathrm{O}_{3}$ correlates with increasing $\mathrm{CO}$ and decreasing $\mathrm{HCl}$ (lines $\mathrm{L} 4)$. In contrast, gradients of stratospheric or TL in-mixing dominate if increasing $\mathrm{O}_{3}$ correlates with increasing $\mathrm{HCl}$ and decreasing $\mathrm{CO}$ (lines L5).

The measurements (Fig. 8c, f) mostly - but not exclusively - show the latter case (L5): neighbouring points form negatively sloped lines in $\mathrm{CO}$ vs. $\mathrm{O}_{3}$ space (black dotted in Fig. 8c), corresponding to horizontal to positively sloped lines in $\mathrm{HCl}$ vs. $\mathrm{O}_{3}$ space (black dotted lines in Fig. 8f). Thus, observed trace gas gradients are mostly due to gradients of stratospheric influence on some well-mixed UT background. This could either be the entrainment of tropospheric air into a more stratospheric background or the entrainment of TL air into a more tropospheric background. There are also a few almost vertical mixing lines in Fig. 8f, indicating case L3 described above. Systematic $\mathrm{HCl}$ gradients - like those across the tropopause - are not expected in convectively uplifted air. $\mathrm{O}_{3}$ variability in such air masses is at least partly due to different amounts of in situ produced $\mathrm{O}_{3}$. However, mixing between aged and young tropospheric air alone cannot explain the observations.

We further note that mixing lines in Fig. $8 \mathrm{f}$ cover similar ranges of $\mathrm{HCl}$, but are separated by different levels of $\mathrm{O}_{3}$. The corresponding background air had seen similar amounts of stratospheric influence, but different $\mathrm{O}_{3}$ production. As long as all points of an individual mixing line are subject to similar $\mathrm{O}_{3}$ production, the entire line will be shifted to different $\mathrm{O}_{3}$ levels. The $\mathrm{O}_{3}$ ranges covered by individual mixing lines are similar to the offsets between different lines. Individual mixing lines in the measurements cover timescales of about $20 \mathrm{~min}$ (Fig. 8c), corresponding to $300 \mathrm{~km}$ at typical HALO speeds. The flight track in the ASMA filament covers more than $3000 \mathrm{~km}$ altogether and multiple mixing lines were found on that scale.

To summarise, our observations of $\mathrm{O}_{3}, \mathrm{HCl}$ and $\mathrm{CO}$ in an ASMA filament show that (i) both photochemical production and TL/stratospheric in-mixing contribute to increased $\mathrm{O}_{3}$ in the observed ASMA filament, and (ii) small-scale gradients of stratospheric influence are superimposed on background regions that are rather homogeneous on small scales (hundreds of kilometres), but differ in their amounts of photochemically produced $\mathrm{O}_{3}$ on larger scales (thousands of kilometres).

\subsection{3 $\mathrm{NO}_{x}$ versus $\mathrm{O}_{3}($ Fig. 9a-c)}

Similar $\mathrm{HCl}$ mixing ratios are simulated throughout the ranges of measured $\mathrm{NO}_{x}$ and $\mathrm{O}_{3}$ (orange box in Fig. 9b). Measurements of increased $\mathrm{NO}_{x}$ in combination with increased $\mathrm{O}_{3}$ (upper right corner of the orange boxes in Fig. 9) are compatible with both increased in situ $\mathrm{O}_{3}$ production and influence from the stratospheric branch. Consequently, $\mathrm{NO}_{x}$ and $\mathrm{O}_{3}$ are well correlated on the scale of our ASMA measurements (Fig. 9c).

$\mathrm{NO}_{x}$ versus $\mathrm{NO}_{y}$ (Fig. 9d-f): There are three distinct regions in Fig. 9d: a blueish stratospheric branch, a dark TL branch and a reddish UT region. As a consequence of the local $\mathrm{NO}_{y}$ minimum directly above the tropopause (Fig. 6d; examples of individual profiles in the Supplement), the most decreased $\mathrm{NO}_{y}$ mixing ratios in Fig. 9d also show up in samples taken from near the tropopause. Measured $\mathrm{NO}$ and $\mathrm{NO}_{y}$ values in the ASMA filament are well correlated (Fig. 9f), which is consistent with almost constant $\mathrm{NO}_{x} / \mathrm{NO}_{y}$ ratios in the UT (Fig. 6e, f). The narrow, linear distribution of the ASMA measurements in Fig. 9c, f can be explained by different amounts of lightning $\mathrm{NO}_{x}$ of approximately the same age.

\section{Simulated intra-annual variability of trace gas dynamics in the monsoon region}

In this section we discuss the evolution of simulated trace gas profiles throughout the year 2012, separately for lateral averages over the western (Iranian) and eastern (Tibetan) ASMA regions (Fig. 2).

\subsection{Ozone}

Steep vertical gradients across the tropopause dominate $\mathrm{O}_{3}$ profiles in the monsoon regions (Fig. 5a, b), but the profiles also show temporal fluctuations on various timescales. Note that our lateral averaging regions are rather large, and smaller-scale structures get smoothed out, e.g. when an $\mathrm{O}_{3}$ poor interior is combined with an $\mathrm{O}_{3}$-rich fringe.

There is increased influx from the stratosphere in spring, enhancing $\mathrm{O}_{3}$ in the UT. This is in accordance with the study by Cristofanelli et al. (2010), but in contrast to their study there are non-negligible $\mathrm{O}_{3}$ enhancements connected to the stratosphere during the monsoon season (Fig. 5b, circled). In this respect our simulation is, however, consistent with trace gas budget considerations for the ASMA (Barret et al., 2016) and the TTL (Konopka et al., 2010). Entrainment from the TL rather than deep from within the stratosphere could reconcile the different findings. No other stratospheric contributions were found for the stratospherically influenced trace gas signatures in the HALO ESMVal ASMA observations.

Enhanced $\mathrm{O}_{3}$ is recognisable in the averaged profiles of the eastern ASMA part only from the tropopause to about $200 \mathrm{hPa}$ below the tropopause, while the mid-troposphere in the Tibetan part is dominated by particularly $\mathrm{O}_{3}$-poor air during the monsoon season (Fig. 5b). The latter is consistent with the findings of Safieddine et al. (2016). $\mathrm{O}_{3}$ depletion in the mid-troposphere of the eastern part is contrasted by enhanced $\mathrm{O}_{3}$ in the mid-troposphere during the monsoon season in the western part (Fig. 5a, circled), marking the wellknown summertime $\mathrm{O}_{3}$ maximum there. 


\subsection{Carbon monoxide}

This is reflected in the evolution of CO profiles in the ASMA region in 2012 (Fig. 5c, d). CO-poor air dominates in the UT during spring, consistent with the stratospheric influx indicated by $\mathrm{O}_{3}$.

CO-rich air rises throughout the troposphere of the eastern part during the monsoon season (Fig. 5d, circled). On the western side there is a conspicuous CO-depleted zone 300 to $500 \mathrm{hPa}$ below the tropopause during the monsoon season (Fig. 5c, circled), while CO is episodically enhanced in the UT. Uplifted air with enhanced CO mixing ratios hardly reaches higher than $450 \mathrm{hPa}$ below the tropopause in summer.

This difference between CO profiles in the Tibetan and the Iranian parts is consistent with the findings of Pan et al. (2016). Occasional horizontal transport in the UT from the eastern to the western part of the ASMA is a possible explanation for the spatio-temporal evolution of $\mathrm{CO}$ mixing ratios, indicating that trace gas signatures in the Iranian part are dominated by the UT outflow of the Tibetan part of the ASMA.

\subsection{Hydrochloric acid}

As expected for a stratospheric tracer, the simulated $\mathrm{HCl}$ profiles (Fig. 5e, f) show a strong anti-correlation with $\mathrm{CO}$ in the UT, with increased $\mathrm{HCl}$ in times of stratospheric influx (e.g. Fig. 5f, blue circle) and decreased $\mathrm{HCl}$ in the monsoon season. Stratosphere-to-troposphere exchange is pronounced during spring, consistent with the seasonality of the BrewerDobson circulation (Holton et al., 1995).

$\mathrm{HCl}$ plumes in the Iranian part rise to about $400 \mathrm{hPa}$ below the tropopause in summer (Fig. 5e, circled), just like $\mathrm{CO}$. Predominantly dry conditions in the western part prevent $\mathrm{HCl}$ from being washed out. However, $\mathrm{CO}$ and $\mathrm{HCl}$ are temporally anti-correlated in the mid-troposphere. Since $\mathrm{HCl}$ is emitted by the sea, we attribute this to alternating marine and continental origins in the uplifted air (Fig. 5c, e).

Some $\mathrm{HCl}$ descends from the tropopause into the midtroposphere, as indicated by tilted patterns of enhanced $\mathrm{HCl}$, which start at the tropopause and propagate downward (marked by an arrow in Fig. 5e). Similar telltale signs of descent is also recognisable in other species in the Iranian part during summer.

There is almost no $\mathrm{HCl}$ in the Tibetan part throughout the monsoon season (Fig. 5f, black circle), except for the UT. Convection and thunderstorms are frequent during the monsoon season in South Asia (Fig. 7d). Wet scavenging and subsequent washing out by precipitation does not affect $\mathrm{CO}$, but effectively prevents transport of $\mathrm{HCl}$ to higher altitudes. Predominantly continental origins also contribute to an increased $\mathrm{CO} / \mathrm{HCl}$ ratio in the rising plumes of the eastern part.

\subsection{Reactive nitrogen}

Simulated $\mathrm{NO}_{x}$ and $\mathrm{NO}_{y}$ profiles in the ASMA region from April to September differ to the rest of the year (Fig. 6ad). E- and C-shaped $\mathrm{NO}_{y}$ profiles dominate the Tibetan and Iranian parts, respectively (Fig. 6c, d; examples of individual profiles in the Supplement).

$\mathrm{NO}_{x}$ and $\mathrm{NO}_{y}$ from boundary layer sources are uplifted, accompanied by conversion of some $\mathrm{NO}_{x}$ into $\mathrm{NO}_{y}$. Solvable $\mathrm{NO}_{y}$ components (e.g. $\mathrm{HNO}_{3}$ ) become increasingly washed out (Fig. 6d), leading to a minimum of reactive nitrogen in the mid-troposphere in the Tibetan part in summer (Fig. 6b, d). Uplift from the lower troposphere is less important for UT $\mathrm{NO}_{x}$ and $\mathrm{NO}_{y}$ than $\mathrm{LiNO}_{x}$ and stratospheric entrainments. The dependence of detrainment on altitude hardly affects trace gas profiles in the mid-troposphere, as indicated by the corresponding $\mathrm{CO}$ profiles (Fig. 5d, circled).

Both $\mathrm{NO}_{x}$ and $\mathrm{NO}_{y}$ gradually increase above the tropopause due to stratospheric photochemistry. Stratospheric influx contributes to increased $\mathrm{NO}_{x}$ mixing ratios in the UT in spring (blue circles in Figs. 5f, 6b), but enhanced UT $\mathrm{NO}_{x}$ during the monsoon (Fig. 6b, black circle) is more due to lightning $\mathrm{NO}_{x}$ emissions in the Tibetan part than to stratospheric entrainments (Supplement).

$\mathrm{NO}_{y}$ can rise to about $400 \mathrm{hPa}$ below the tropopause in the heat low over the Arabian Peninsula (circled in Fig. 6c). Downward transport (as indicated by anti-clockwise tilted signals, one example marked by an arrow in Fig. 6c) dominates above that altitude, preventing further uplift. With little in situ production of lightning $\mathrm{NO}_{x}$ over the Arabian Peninsula in summer (Figs. 7c and 10), UT NO ${ }_{y}$ in the Iranian part is dominated by the outflow of the Tibetan part.

As a combination of the different processes affecting $\mathrm{NO}_{x}$ and $\mathrm{NO}_{y}$, the $\mathrm{NO}_{x} / \mathrm{NO}_{y}$ ratio maintains a broad maximum in the TL throughout the year (Fig. 6e, f). During the monsoon, the $\mathrm{NO}_{x} / \mathrm{NO}_{y}$ ratio in the UTLS is larger in the western than in the eastern ASMA part (Fig. 6e, f, circles). This indicates preferential export of high- $\mathrm{NO}_{x}$ air from the Tibetan part or is an artefact of the possible dominance of a single source of $\mathrm{LiNO}_{x}$ in the Iranian region (Fig. 10).

\section{Processes and their interplay in the ASMA}

In this section the observed and simulated trace gas signatures are related to simulated photochemical, transport and mixing properties of the ASMA. The term "interplay" is thereby used in a neutral sense regarding the direction of feedbacks between different processes: it subsumes mostly one-way interactions (e.g. emissions affecting $\mathrm{O}_{3}$ production, dynamics affecting trace gas distributions). We note upfront that the intra-annual variability of trace gas dynamics in the Tibetan and Iranian ASMA regions discussed for the 


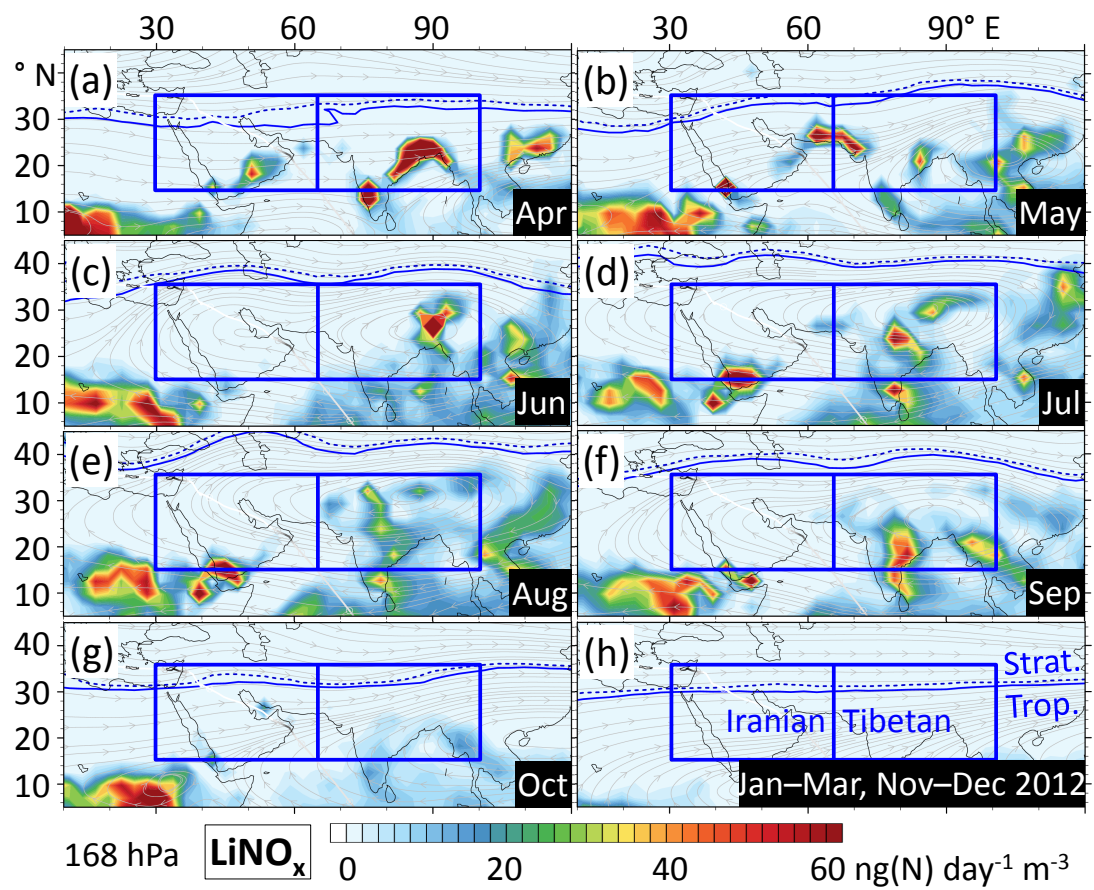

Figure 10. Simulated monthly mean lightning $\mathrm{NO}_{x}$ emission rates in 2012 at a pressure level corresponding to the HALO ESMVal measurements. Months with almost no emissions are combined in panel (h). The ASMA circulation dominates in the monthly mean wind fields from June to September, as shown by streamlines (grey). There are strong, localised emissions in spring (April-May), which in the Iranian part hardly reach the $355 \mathrm{~K}$ level. In contrast, $\mathrm{LiNO}_{x}$ emissions are distributed throughout the Tibetan region in summer (July-September). The simulated spatio-temporal emission patterns are similar for 2013 and 2014 (not shown).

year 2012 in Sect. 5 is largely similar to the other considered years (2010-2014; shown in the Supplement).

\subsection{Lightning $\mathrm{NO}_{x}$}

In our EMAC simulations, $\mathrm{LiNO}_{x}$ is released based on a parameterisation that links flash frequency to updraught velocity in - also parameterised - convection. It is difficult to pinpoint $\mathrm{LiNO}_{x}$ emissions (Schumann and Huntrieser, 2007), and both parameterisations are a notorious source of uncertainty in global models. The parameterisations for convection (Tiedtke, 1989; Nordeng, 1994; Tost, 2006) and lightning (Grewe et al., 2001) used in our simulations have been tested in several studies (Tost et al., 2007; Grewe, 2009; Lopez, 2016) and appear to be state of the art. EMAC-simulated lightning activity matches the corresponding TRMM-LIS/OTD (Tropical Rainfall Measuring Mission Lightning Imaging Sensor/Optical Transient Detector) observations (Cecil, 2006) reasonably well, spatially and temporally (Supplement). Simulated and observed NO along the HALO ESMVal flight track agree remarkably well within the ASMA region (accompanying paper). The same is true for comparisons of IAGOS-CARIBIC measurements of NO and our simulation's output along the IAGOS-CARIBIC flight tracks, where the agreement is particularly noticeable for the monsoon season in the ASMA region (Supplement). A ded- icated comparison to other models is still desirable, since $\mathrm{NO}_{x}$ is complex to simulate and there might be compensating errors. For the current study, however, the above comparisons provide some confidence that $\mathrm{LiNO}_{x}$ emissions have been captured well by the simulation.

Simulated $\mathrm{LiNO}_{x}$ emission rate profiles for 2012 show prominent maxima for the eastern and western ASMA regions during spring (Fig. 7c, d). Overall, $\mathrm{LiNO}_{x}$ emissions are much stronger in the Tibetan part. The emissions reach up to the tropopause throughout the year, implying that $\mathrm{LiNO}_{x}$ is emitted at higher potential temperatures during the monsoon season (Fig. 4b). Despite higher emission rates in the laterally averaged profiles (Fig. 4d), lightning activity in the Tibetan part is more sporadic and localised in spring than in summer (Fig. 10d, e). During the monsoon season, $\mathrm{LiNO}_{x}$ is constantly replenished in the ASMA throughout the region (Fig. $10 \mathrm{~g}, \mathrm{~h}, \mathrm{i}$ ). Sensitivity simulations show that UT $\mathrm{NO}_{x}$ (Fig. 6b) is mainly $\mathrm{LiNO}_{x}$ during the monsoon season (Supplement).

\subsection{Entrainment of lower-tropospheric air}

The uplift of lower-tropospheric air to the UT is a wellknown characteristic of the ASMA (Pan et al., 2016). Simulated CO profiles in the Tibetan region show episodes of such uplift, not only for 2012 (Fig. 5d), but for every mon- 


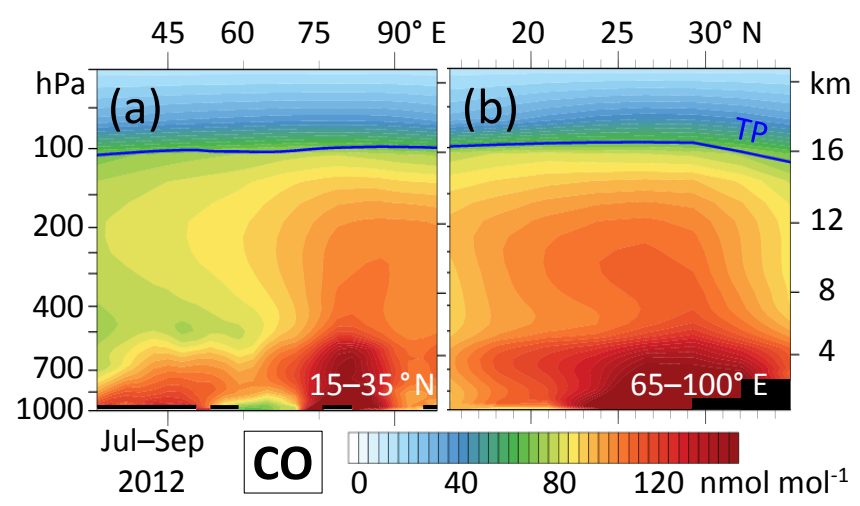

Figure 11. Simulated 3-month mean vertical cross sections of CO mixing ratios: (a) Covering Iranian and Tibetan parts, meridional mean; (b) Tibetan part, zonal mean. On average, the hotspot of ascending $\mathrm{CO}$ in our simulation is located at about $29^{\circ} \mathrm{N}, 80^{\circ} \mathrm{E}$, corresponding to the south-western flank of the Himalayas.

soon season during 2010-2014 (Supplement). This is consistent with the HALO ESMVal measurements, since the trace gas gradients observed in the ASMA can be explained by mixing between lower-tropospheric air and stratospherically influenced air.

$\mathrm{CO}$ uplift to the UT and $\mathrm{LiNO}_{x}$ emissions are both related to convection and it is remarkable that there is a much stronger correlation between the two in summer than in spring (Figs. 5d, 7d). We attribute this to three effects: (i) the large-scale uplift at the south-western flank of the Himalayas is only active during the monsoon season and is not exclusively driven by deep convection (see Sects. 1, 3). It has been suggested to be the main transport pathway of pollutants to the UT (Bergman et al., 2013; Pan et al., 2016), which is supported by our simulation (Fig. 11) and the location of maximum moist static energy (Boos and Hurley, 2013). Back-trajectory calculations in the accompanying paper identified this pathway as the source of enhanced $\mathrm{CO}$ in some of the HALO ESMVal measurements, despite the underlying reanalysis not accounting for (small scale) convection. (ii) In the UT the ASMA is a leaky transport barrier, allowing some accumulation of the uplifted pollutants (Pan et al., 2016). There is no such transport barrier in spring. (iii) The spatial and temporal matches of deep convection and increased $\mathrm{CO}$ at different altitudes reflect the potential for entrainment and subsequent convective transport of $\mathrm{CO}$ (Fig. $7 \mathrm{~g}, \mathrm{~h}$ ). It is clearly increased in summer. More detailed analyses (Supplement) show that convection is localised over the coastal regions of West Bengal and Bangladesh in April 2012. In contrast, during August 2012 convection is ubiquitous throughout the Tibetan region. It is most persistent at the south-western flank of the Himalayas and over the Tibetan plateau. This coincides with the highest $\mathrm{CO}$ mixing ratios, which accumulate there due to the prevalent south-westerly winds during the monsoon season. Con- sequently, more $\mathrm{CO}$ is transported through the troposphere in the Tibetan region during summer.

\subsection{Photochemical $\mathrm{O}_{3}$ production and ageing}

The net photochemical $\mathrm{O}_{3}$ production rate (Fig. $7 \mathrm{a}, \mathrm{b}$ ) is derived from the difference between EMAC-simulated diagnostic tracers $\mathrm{ProdO}_{3}$ and $\mathrm{LossO}_{3}$ (Jöckel et al., 2016). Here we take into account effective $\mathrm{O}_{3}$ production and loss terms following Crutzen and Schmailzl, (1983) and extended by Grewe et al. (2017; see their Supplement). There are known high- $\mathrm{O}_{3}$ biases in the simulation (Jöckel et al., 2016), and uncertainties in the chemical mechanism (Gottschaldt et al., 2013) also impose uncertainties onto $\mathrm{O}_{3}$ photochemistry. Nevertheless our simulated net $\mathrm{O}_{3}$ production rates in the ASMA (Fig. 7b) agree remarkably well with the independent estimate by Barret et al. (2016).

$\mathrm{O}_{3}$ photochemistry is dominated by catalytic cycles in the troposphere and affected by a variety of parameters, e.g. ambient mixing ratios of $\mathrm{H}_{2} \mathrm{O}, \mathrm{O}_{3}, \mathrm{CO}$ and $\mathrm{NO}_{x}$ (Ehhalt and Rohrer, 1994; Grooß et al., 1998; Jaeglé et al., 1998; Seinfeld and Pandis, 1998). We focus on $\mathrm{NO}_{x}$ and $\mathrm{CO}$ for illustration (Fig. 12). Photochemical $\mathrm{O}_{3}$ production ${ }^{1}\left(\operatorname{ProdO}_{3}\right)$ non-linearly depends on ambient $\mathrm{NO}_{x}$ mixing ratios: it increases proportional to $\mathrm{NO}_{x}$ in the $\mathrm{NO}_{x}$-limited regime, is almost independent of $\mathrm{NO}_{x}$ variations at higher $\mathrm{NO}_{x}$ mixing ratios, and a further increase of $\mathrm{NO}_{x}$ even leads to decreasing $\mathrm{ProdO}_{3}\left(\mathrm{NO}_{x}\right.$-saturated regime). Increasing $\mathrm{CO}$ increases $\mathrm{ProdO}_{3}$ and shifts the point of maximum $\mathrm{ProdO}_{3}$ to higher $\mathrm{NO}_{x}$. Increasing $\mathrm{H}_{2} \mathrm{O}$ impacts $\mathrm{ProdO}_{3}$ in a qualitatively similar way to increasing $\mathrm{CO}$. Decreasing $\mathrm{O}_{3}$ leads to higher ProdO $_{3}$, but $\mathrm{NO}_{x}$ at the point of maximum $\mathrm{ProdO}_{3}$ is at its lowest for medium $\mathrm{O}_{3}$ mixing ratios.

The simulation shows the superposition of the above effects, among others within the full complexity of the chemical mechanism. As a result, a net $\mathrm{O}_{3}$-producing photochemistry prevails in the ASMA throughout the monsoon season (circled in Fig. 7a, b). This is accompanied by net $\mathrm{O}_{3}$ destruction during the monsoon season, $300 \mathrm{hPa}$ below the tropopause and lower. At the tropopause and slightly above, there is a local minimum of net $\mathrm{O}_{3}$ production, followed by increased net $\mathrm{O}_{3}$ production in the stratosphere. Net $\mathrm{O}_{3}$ production is at maximum in the altitude range, where uplifted young air (enriched in $\mathrm{CO}$ and co-emitted volatile, organic $\mathrm{O}_{3}$ precursors) mixes with $\mathrm{NO}_{x}$-rich UT air (Figs. $5 \mathrm{~d}, 6 \mathrm{~b}$, $7 b)$.

ProdO $O_{3}$ per $\mathrm{NO}_{x}$ shows a strong gradient at the altitude of maximum net $\mathrm{O}_{3}$ production (circled in Fig. $7 \mathrm{~b}, \mathrm{f}$ ). This indicates the transition from the $\mathrm{NO}_{x}$-limited to the $\mathrm{NO}_{x}$ saturated regime (Fig. 12), but is superimposed by gradients of $\mathrm{CO}$ and other $\mathrm{O}_{3}$ precursors. The maximum corresponds to about $300 \mathrm{pmol} \mathrm{mol}^{-1} \mathrm{NO}_{x}$ (circled in Fig. 8h), and vari-

\footnotetext{
${ }^{1} \mathrm{Net} \mathrm{O}_{3}$ production in the UT is determined by $\mathrm{ProdO}_{3}$ rather than by $\mathrm{LossO}_{3}$ (Supplement, Figs. S6, S9, S17), so it is sufficient to analyse $\mathrm{ProdO}_{3}$ in this context.
} 


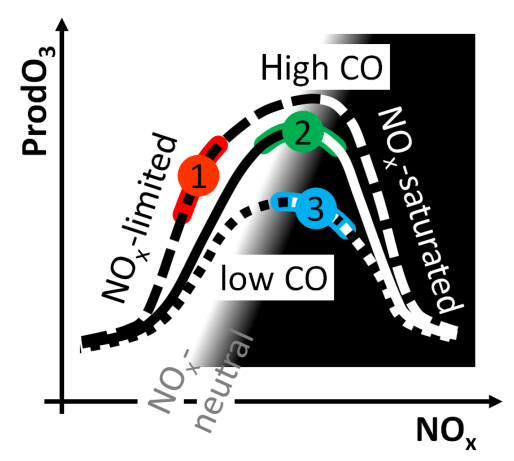

Figure 12. Schematic of the dependence of photochemical $\mathrm{O}_{3}$ production $\left(\mathrm{ProdO}_{3}\right)$ on $\mathrm{NO}_{x}$ and $\mathrm{CO}$ mixing ratios (after Grooß et al., 1998). Red, green and blue highlight photochemical conditions that are discussed in the text. Approximate numbers (Ehhalt and Rohrer, 1994; Jaeglé et al., 1998; Grooß et al., 1998) for UT conditions at northern midlatitudes the point of maximum $\mathrm{O}_{3}$ production may vary between 200 and $700 \mathrm{pmol} \mathrm{mol}^{-1} \mathrm{NO}_{x}$. The maximum net $\mathrm{O}_{3}$ production varies by a factor of about 4 , depending on ambient conditions.

ations of $\mathrm{NO}_{x}$ in that region have a relatively small effect on net $\mathrm{O}_{3}$ production (2 in Fig. 12).

Going down from the TP in the ASMA, $\mathrm{NO}_{x}$ and $\mathrm{O}_{3}$ generally decrease, while $\mathrm{CO}$ and $\mathrm{H}_{2} \mathrm{O}$ increase (Figs. 5, 6; $\mathrm{H}_{2} \mathrm{O}$ not shown). It is a multi-dimensional problem. $\mathrm{CO}$ (among others) determines the curve in the $\mathrm{NO}_{x}$ vs. ProdO 3 diagram, and $\mathrm{NO}_{x}$ determines the operating point on the curve. Considering typical ranges of $\mathrm{CO}$ and $\mathrm{NO}_{x}$ in different parts of the ASMA, an area on the surface in $\mathrm{ProdO}_{3}-\mathrm{NO}_{x}-\mathrm{CO}$ space is termed "operating mode of the chemical system" in the following. Different chemical regimes (e.g. $\mathrm{NO}_{x}$-limited or $\mathrm{NO}_{x}$-saturated) are allowed within one operating mode. The non-linear dependence of $\mathrm{ProdO}_{3}$ on ambient trace gas mixing ratios leads to the simulated maximum within the opposite gradients of those trace gases $\left(\mathrm{NO}_{x}\right.$ decreases below the $\mathrm{TP}$, while CO increases) in the UT ASMA. Going down from the TP, the chemical system goes from operating mode 3 to 2 to 1 (Fig. 12). In principle, all those operating modes could be in the $\mathrm{NO}_{x}$-limited regime and still lead to a maximum of net $\mathrm{O}_{3}$ production in the UT. However, our simulations also show the $\mathrm{NO}_{x}$-saturated regime (Supplement).

Periods of enhanced lightning $\mathrm{NO}_{x}$ in spring (circled in Fig. 7d) correspond to increased net $\mathrm{O}_{3}$ production (Fig. 7b), but despite higher $\mathrm{LiNO}_{x}$ emissions in spring, net $\mathrm{O}_{3}$ production is at maximum in the ASMA. The main differences between the seasons are that there is less $\mathrm{CO}$ in the UT during spring (Fig. 5d) and lightning $\mathrm{NO}_{x}$ is available only locally (Sect. 6.1. and Supplement). More CO in the UTLS in summer increases $\mathrm{ProdO}_{3}$ and the maximum possible $\mathrm{O}_{3}$ production (Fig. 12). Too high $\mathrm{NO}_{x}$ in spring does not help $\mathrm{ProdO}_{3}$ - or even pushes the system into the $\mathrm{NO}_{x}$-saturated regime (3 in Fig. 12). $\mathrm{NO}_{x}$ close to maximum $\mathrm{ProdO}_{3}$ conditions (2 in Fig. 12) throughout the region in summer leads to higher $\mathrm{ProdO}_{3}$ in the lateral average.

Both $\mathrm{NO}_{x}$ and other precursors are more abundant in the UT of the Tibetan part, resulting in larger photochemical $\mathrm{O}_{3}$ production than in the Iranian part (Fig. 7a, b). This is consistent with other studies (J. J. Liu et al., 2009; Barret et al., 2016), which have also found such an asymmetry. $\mathrm{O}_{3}-$ depleting conditions prevail in the mid-troposphere over the Arabian Peninsula throughout the summer (Fig. 7a, circled). Thus increased $\mathrm{O}_{3}$ there (Fig. 5a) must be due to transport.

Confinement in the ASMA circulation allows the mixed air to age, i.e. to produce $\mathrm{O}_{3}$. $\mathrm{CO}$ is being depleted in the process of ageing, and $\mathrm{NO}_{x}$ is transferred to $\mathrm{NO}_{y}$. The other source of aged air is entrainment from the TL, which is, however, enriched in $\mathrm{HCl}$ (at least within the photochemical lifetime of $\mathrm{HCl}$ ). $\mathrm{O}_{3}$ is produced in the ASMA at a net rate of about $4 \mathrm{nmol} \mathrm{mol}^{-1}$ day $^{-1}$ (Fig. 7b), and simulated $\mathrm{O}_{3}$ mixing ratios in the UT of the ASMA region vary by about $120 \mathrm{nmol} \mathrm{mol}^{-1}$ (Fig. 8b). It would take 30 days to cover that range by photochemical $\mathrm{O}_{3}$ production alone. The observed values in the ASMA filament cover a range of about $48 \mathrm{nmol} \mathrm{mol}^{-1}$ (Fig. 8c), corresponding to 12 days of photochemical $\mathrm{O}_{3}$ production. According to the trajectory calculations in the accompanying paper, this is about the time needed to circle the ASMA. The above $\mathrm{O}_{3}$ variability of course includes different amounts of $\mathrm{O}_{3}$ from the TL, and $\mathrm{O}_{3}$ productivity varies too. Neglecting these uncertainties, it takes one or two rotations of the ASMA to transform $\mathrm{O}_{3}$ depleted, freshly uplifted air into aged, $\mathrm{O}_{3}$-enhanced air. $\mathrm{O}_{3}$ depletion in the ASMA relative to the regional average can only be maintained by frequent replenishment of young air.

\subsection{Entrainment of tropopause layer air}

Here we focus on the less well-known entrainment of stratospheric or TL air into the free troposphere, which is supported by the unique thermodynamic conditions over the Tibetan plateau in summer (Fig. 2). The prevailing northerly winds (Kunze et al., 2010) of the eastern ASMA flank (Fig. 2) tend to transport high potential vorticity (stratospheric or TL, Fig. 4c) air along the isentropic surfaces into the troposphere (Ren et al., 2014; Kunz et al., 2015). This effect was also detected by Konopka et al. (2010) as enhanced horizontal transport of $\mathrm{O}_{3}$-rich air from the extratropics into the TTL. This transport from the TL or even the extratropical lower stratosphere into the free tropical troposphere may not leave a telltale sign of increased potential temperature in the corresponding air masses in the tropics. This includes the $350-370 \mathrm{~K}$ isentropes that were encountered during the HALO ESMVal campaign in the tropics (Fig. 4; $\theta$ estimates for the measurements are shown in the Supplement).

Additional stratospheric or TL contributions at the outer ASMA edge, other than at the eastern flank, are also plausible. The eastern Mediterranean and central Asian region is a global hotspot of tropopause-folding activity (Tyrlis et 
al., 2014), which is related to ASMA dynamics and generates enhanced $\mathrm{O}_{3}$ levels through stratosphere-troposphere exchange (Akritidis et al., 2016). If the ASMA circulation encompasses that tropopause folding hotspot, it may pick up stratospheric entrainments.

Stratospheric influence is manifested in our measurements by increased $\mathrm{HCl}$ mixing ratios in combination with other tracers (Sect. 4.3).

Did the HALO ESMVal campaign encounter an exceptional situation, or does TL entrainment at the eastern ASMA flank occur more often? The synoptic situation in question is characterised by a filament of enhanced $\mathrm{HCl}$ that is carried along the south-eastern ASMA flank, around a HCl-depleted ASMA interior. Here we analyse the evolution of simulated $\mathrm{HCl}$ mixing ratios at $\theta=355 \mathrm{~K}$, on a meridional $(\mathrm{N}-\mathrm{S})$ transect at $90^{\circ} \mathrm{E}$, throughout the monsoon seasons of 2010 to 2014. The transition between eastward and westward winds indicates the location of the ASMA centre on the meridional transect, which wobbles around $30^{\circ} \mathrm{N}$ (white "ridgeline" in Fig. 3b). Enhanced tropospheric $\mathrm{HCl}$ mixing ratios south of the ridgeline serve as an indicator of TL entrainment (Fig. 3c). Caution with this interpretation is only needed at times when the ASMA is shifted to the west (compare Fig. 3a), because the transect in Fig. 3c may then be too far within the eastern ASMA flank. Episodes of increased $\mathrm{HCl}$ in the southern or eastern ASMA flank cover at least half of the time axis, showing that entrainment of TL air into the ASMA circulation is quite a common process. One horizontal slice from each analysed month is shown in the Supplement, indicating that filaments of enhanced $\mathrm{HCl}$ often protrude from a TP trough of a Rossby wave at the eastern ASMA flank. The association of this mixing process with planetary wavebreaking events is a topic of ongoing research (Lubis and Nakamura, 2017).

\subsection{Radial stratification and patchy trace gas distributions}

Deep convection from the lower troposphere discharges more towards the ASMA interior, as shown by studies that report relatively young air there ( $\mathrm{Li}$ et al., 2005; Randel and Park, 2006; Park et al., 2008; Y. Liu et al., 2009; Kunze et al., 2010; Liu et al., 2011; Santee et al., 2017) and also by our simulation (Sect. 6.4). In contrast, trace gas signatures in a belt of outer streamlines are dominated by a combination of photochemically aged lower-tropospheric air and entrainments of UT air surrounding the ASMA. In this schematic of an undisturbed anticyclone, interior trace gas signatures are generally characterised by lower $\mathrm{O}_{3}$ mixing ratios than fringe signatures. This radial zoning in the ASMA is an expression of almost closed circulation and was observed in IAGOS-CARIBIC in situ data of flights between Chennai, India and Frankfurt, Germany (Baker et al., 2011; RautheSchöch et al., 2016). Increased $\mathrm{O}_{3}$ mixing ratios were found in the northern part of the ASMA and decreased levels towards the southern end of the flights.

Radial stratification is counteracted by the general on-off nature of TL entrainment, upwellings from the lower troposphere and lightning. Still considering only undisturbed ASMA circulation, all those effects lead to patches of air with different trace gas signatures. Each of these patches might again receive contributions from any of the above sources. In principle all sorts of combinations are possible, generating heterogeneity. In contrast, mixing and photochemical ageing are homogenising effects. In combination with closed streamlines the preferential positions of the different sources might still show up as radial stratification in the ASMA, or show up in individual situations (Sect. 6.4).

However, neither the HALO ESMVal measurements nor sequences of simulated snapshots (Supplement) show clear stratification. The idealised picture that the ASMA circulation is dominated by stationary, closed streamlines is certainly not realistic - at least not on the timescales of the homogenising effects.

\subsection{Splitting-up and stirring}

Transient streamlines, particularly eddy shedding or splitting of the ASMA, effectively overcome radial transport barriers. Whether stratified or patchy - any trace gas distribution in the ASMA might then be subject to effective stirring. There is an ongoing discussion about different dynamical modes of the ASMA (Nützel et al., 2016; Pan et al., 2016).

A splitting-up event occurred during the HALO ESMVal campaign, corresponding to the transition from a longitudinally elongated phase to a double centre phase in the nomenclature of Pan et al. (2016). A sequence of simulated streamlines and tracer distributions shows that parts of the fringe of the elongated anticyclone become part of the interiors of both resulting anticyclones after the splitting, and the interior parts are diverted into the fringes (Fig. 13). Even if not all possible cases are covered by the example, it is easily conceivable that the some or all of the fringing parts may stay in the fringes and some or all of the interior parts in the interiors. For a given location and timing of eddy shedding or splitting, the final trace gas distribution simply depends on the initial distribution of different patches. The redistribution of different parts of the anticyclone guarantees a high variability for outflow and interior, whenever the closed circulation breaks down.

How often does this happen? Splitting and eddy shedding mainly occur in a zonal $(\mathrm{E}-\mathrm{W})$ direction, whereby the transition from a northward wind in the west to a southward wind in the east indicates the centre of an anticyclone or eddy. We analyse the evolution of meridional winds at $\theta=355 \mathrm{~K}$, on a wide $\left(15-35^{\circ} \mathrm{N}\right)$ zonal transect, throughout the monsoon seasons of 2010 to 2014 (Fig. 3a).

The pattern at the given altitude is consistent with one dominating anticyclone, centred at about $90^{\circ} \mathrm{E}$. While the 


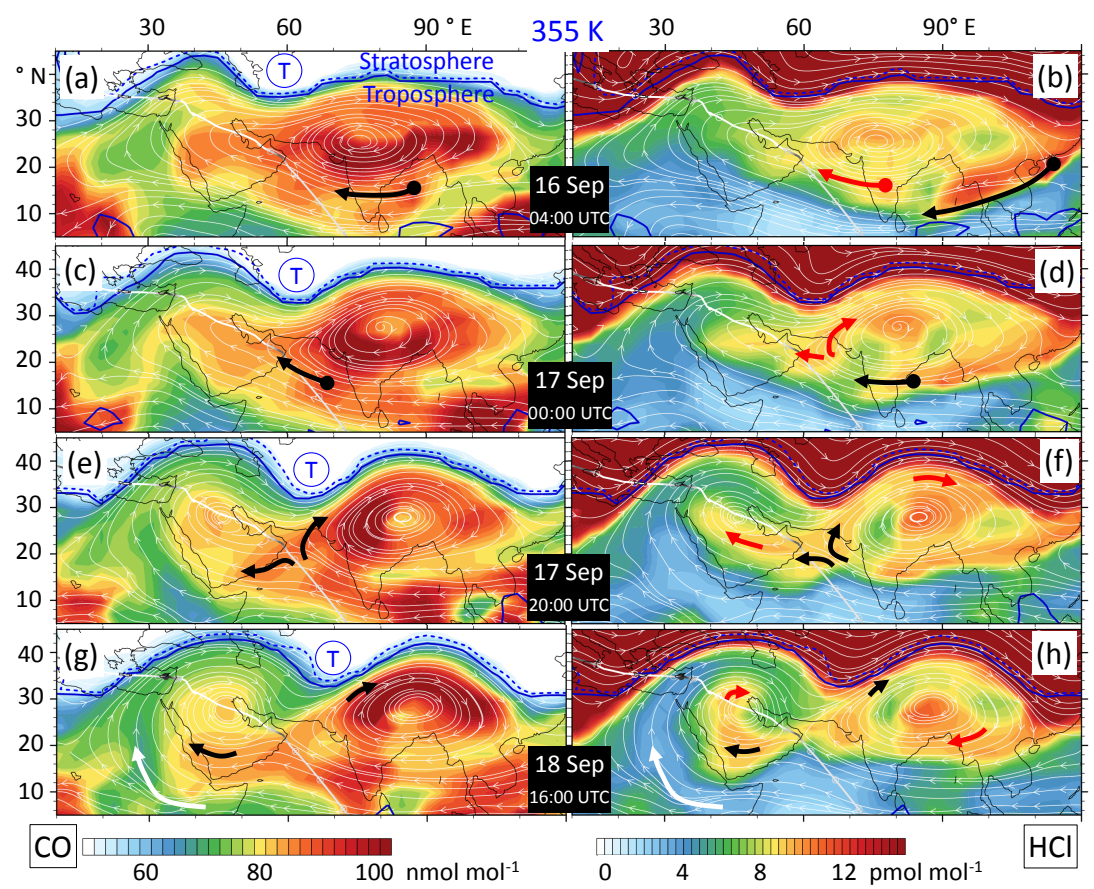

Figure 13. Sequence of simulated tracer fields at $355 \mathrm{~K}$, illustrating the stirring associated with the splitting-up event of the ASMA that occurred during the HALO ESMVal campaign in September 2012. Streamlines (grey) represent instantaneous wind fields, and arrows highlight the redistribution of selected air masses. $\mathrm{CO}$ mainly originates in the ASMA interior and $\mathrm{HCl}$ serves as a proxy with which to track the ASMA fringe. The sequence starts with an elongated anticyclone on 16 September 2012. Then a tropopause trough (T) evolves from the west along the northern ASMA flank. The anticyclone succumbs to the perturbation and splits up into a Tibetan and an Iranian part, shortly after the HALO flight from Male to Larnaca had passed through. A part of the increased CO interior region is entrained by the outer streamlines of the Iranian part, while the rest of the patch is diverted into the interior of the Tibetan anticyclone (black arrows in the left panels). The evolution of freshly entrained $\mathrm{HCl}$ (black arrows) and an older patch (red arrows) are shown in the right panels. We also note entrainment of tropospheric air by southerly winds at the western flank (white arrows).

northerly winds east of $90^{\circ} \mathrm{E}$ are relatively persistent, episodes of entirely southerly winds in the western part of the one-piece ASMA alternate with episodes of smaller, secondary anticyclones. Smaller anticyclones also regularly occur east of the Tibetan anticyclone, corresponding to eddy shedding to the east. The splitting event that occurred during the HALO ESMVal campaign is clearly visible in Fig. 3a, too. Such instabilities occur approximately twice a month. This coincidentally corresponds to the timescale needed to photochemically erase $\mathrm{O}_{3}$-depleted signatures in young air masses.

\section{Summary}

This study complements a detailed analysis of in situ trace gas measurements in the ASMA, obtained during the ESMVal campaign with the research aircraft HALO in September 2012 (Gottschaldt et al., 2017). The measurements are put in the context of the EMAC-simulated annual evolution of trace gas profiles in the ASMA region and simulated tracer-tracer relations. This led to the following qualitative understanding of the interplay of processes that determine the trace gas dis- tributions in the ASMA and its outflow (Fig. 14): Air from the steeply inclined TL is entrained by outer ASMA streamlines at the eastern and possibly northern ASMA flank, defining a fringing zone. Tropopause troughs facilitate the entrainment.

Stratospherically enhanced tracers like $\mathrm{HCl}$ and $\mathrm{O}_{3}$ are reflected in the entrained air. Thus, the fringe is not just a transport barrier, separating the ASMA interior from the surrounding UT. It has a distinct genesis, resulting in air masses with distinct trace gas signatures that may be transported relatively unperturbed over long distances. Deep convection and a conduit of upwelling air over the Tibetan plateau (Bergman et al., 2013) inject lower-tropospheric air mainly into the Tibetan part of the ASMA. Enhanced CO is an indicator for this process. Convection is accompanied by in situ production of lightning $\mathrm{NO}_{x}$, mainly determining mixing ratios of this $\mathrm{O}_{3}$ precursor in the ASMA.

In the idealised case of one intact anticyclone (Fig. 14a) the interior would then be dominated by photochemical ageing of those $\mathrm{O}_{3}$-poor injections. Net $\mathrm{O}_{3}$ production dominates in the ASMA and is particularly enhanced where mainly lower-tropospheric $\mathrm{O}_{3}$ precursors $(\mathrm{CO}$, volatile or- 

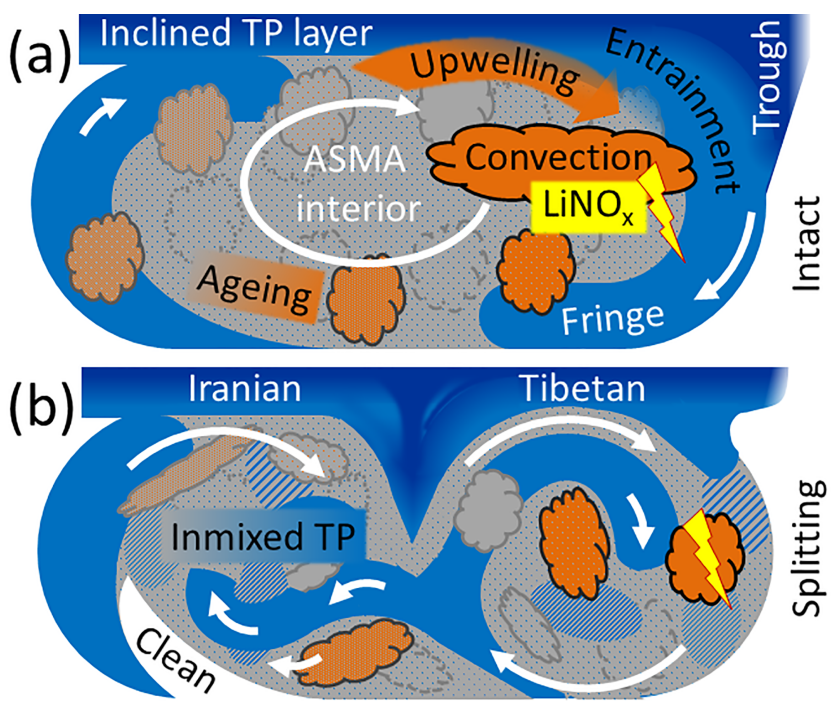

Figure 14. Schematic of processes determining trace gas distributions in the ASMA at a UT level: (a) One undisturbed anticyclone, encompassing the Tibetan and Iranian regions. (b) Splitting into an Iranian and a Tibetan part. See text for details.

ganic compounds) meet UT precursors $\left(\mathrm{NO}_{x}\right)$. The preferential positions of convective versus TL entrainments facilitate radial stratification in the ASMA. The intermittent nature of the entrainments, combined with the varying position of the anticyclone, leads to patches of air that have different origins and are in different stages of ageing. Mixing and ageing are homogenising, but each of these patches might again receive fresh entrainments from the TL or by convection and lightning.

Eddy shedding or transitions between other dynamical modes of the ASMA effectively overcome radial transport barriers (Fig. 14b, summarising Figs. 13 and S18 in the Supplement). Whether stratified or patchy, any trace gas distribution in the ASMA is subject to effective stirring. Fringe air can be diverted into the interiors of both anticyclones, and likewise interior air is redistributed throughout the UT in the monsoon region. Remnants of earlier such events gradually lose memory of their origins, leading to a mixed background (grey in Fig. 14b).

We found that the processes that led to the curious combination of both enhanced lower tropospheric and TL tracers in the ASMA filaments encountered by the HALO ESMVal campaign are not exceptional: entrainment of TL air and dynamical instabilities of the ASMA occur quite frequently. Deep convection and thunderstorms are common throughout the monsoon season, accompanied by a net $\mathrm{O}_{3}$ producing photochemical regime. The alternating interplay of those processes results in highly variable, patchy trace gas distributions in the ASMA. Processes that increase $\mathrm{O}_{3}$ and its precursors dominate in the Tibetan part of the ASMA. The Iranian part is dynamically dominated by the Tibetan part in the UT. $\mathrm{O}_{3}$-rich TL entrainments and precursor-rich air, both of which are main ASMA components, tend to increase $\mathrm{O}_{3}$ in the tropospheric ASMA outflow - e.g. over the Arabian Peninsula.

Data availability. The simulation results analysed here are archived at the German Climate Computing Center (DKRZ) and are available on request. It is planned to move them to the Climate and Environmental Retrieval and Archive (CERA) database at the German Climate Computing Centre (DKRZ; https://cera-www. dkrz.de, last access: 18 April 2018). The corresponding digital object identifiers (DOIs) will be published on the MESSy consortium web page (http://www.messy-interface.org, last access: 9 April 2018). The observational data of the HALO ESMVal flight used here are available from the HALO database (re3data.org, 2018). We used the NCAR Command Language (NCL) for data analysis and to create some of the figures of this study. NCL is developed by UCAR/NCAR/CISL/TDD and available online (UCAR/NCAR/CISL/TDD, 2017).

Supplement. The supplement related to this article is available online at: https://doi.org/10.5194/acp-18-5655-2018-supplement.

Author contributions. KDG analysed the EMAC and final in situ data, conducted the Lagrangian calculations, produced the plots and drafted the paper. HS conceived the study, led the HALO ESMVal campaign and interpreted EMAC and in situ data. RB wrote and helped with the code that facilitated the HYSPLIT calculations. PJ led the ESCiMo project, coordinated the preparation of the EMAC simulations and conducted them. DSC and PG prepared a significant part of the boundary conditions, and VG was responsible for the $\mathrm{ProdO}_{3}$ and $\mathrm{LossO}_{3}$ diagnostics in the ESCiMo simulations. VE conceived and led the ESMVal project. TJW, CV, AZ and HZ supplied in situ measurements. All authors contributed to the text.

Competing interests. The authors declare that they have no conflict of interest.

Special issue statement. This article is part of the special issue "The Modular Earth Submodel System (MESSy) (ACP/GMD interjournal SI)". It is not associated with a conference.

Acknowledgements. The authors gratefully thank Hella Garny and Peter Hoor for valuable comments on the manuscript, Angela Baker, Brice Barret, Björn Brötz, James Crawford, Franziska Frank, Heidi Huntrieser, Paul Konopka, Rolf Müller, Matthias Nützel, Laura Pan, Rongcai Ren, Michelle Santee, Michael Schultz, Gabriele Stiller and Bärbel Vogel for helpful discussions, and the ACAM (Atmospheric Composition and the Asian Monsoon; http://www2.acom. ucar.edu/acamTS13, last accessed: 9 April 2018) activity for providing a forum. We thank the German Science Foundation (DFG) for funding within HALO-SPP 1294 under the contracts JU 3059/1- 
1, SCHL 1857/2-2, SCHL 1857/4-1, VO 1504/2-1 and VO 1504/41. The HALO ESMVal aircraft campaign was funded by the DLR project ESMVal. Klaus-Dirk Gottschaldt and Hans Schlager appreciate support by the EU project StratoClim (grant no. 603557) and BMBF project Spitfire (grant no. 01LG1205B). Christiane Voigt and Tina Jurkat-Witschas are thankful for financing from the Helmholtz Association under contract no. VH-NG-309 and under contract no. W2/W3-60. In addition we thank the flight department of DLR for their great support during the campaign. Peter Hoor and Stefan Müller contributed to the $\mathrm{CO}$ measurements and Stefan Kaufmann supervised the $\mathrm{HCl}$ measurements during the flight.

The EMAC model simulations were performed at the German Climate Computing Centre (DKRZ) with support from the Bundesministerium für Bildung und Forschung (BMBF). DKRZ and its scientific steering committee are gratefully acknowledged for providing the HPC and data archiving resources for the projects 853 (ESCiMo - Earth System Chemistry integrated Modelling) and 854 (ESMVal).

Last but not least we thank the two anonymous reviewers for their insightful comments regarding $\mathrm{LiNO}_{x}$, convective and isentropic transport, which greatly helped to improve the paper.

The article processing charges for this open-access

publication were covered by a Research

Centre of the Helmholtz Association.

Edited by: Marc von Hobe

Reviewed by: two anonymous referees

\section{References}

Akritidis, D., Pozzer, A., Zanis, P., Tyrlis, E., Škerlak, B., Sprenger, M., and Lelieveld, J.: On the role of tropopause folds in summertime tropospheric ozone over the eastern Mediterranean and the Middle East, Atmos. Chem. Phys., 16, 14025-14039, https://doi.org/10.5194/acp-16-14025-2016, 2016.

Baker, A. K., Schuck, T. J., Slemr, F., van Velthoven, P., Zahn, A., and Brenninkmeijer, C. A. M.: Characterization of nonmethane hydrocarbons in Asian summer monsoon outflow observed by the CARIBIC aircraft, Atmos. Chem. Phys., 11, 503518, https://doi.org/10.5194/acp-11-503-2011, 2011.

Barret, B., Sauvage, B., Bennouna, Y., and Le Flochmoen, E.: Upper-tropospheric $\mathrm{CO}$ and $\mathrm{O}_{3}$ budget during the Asian summer monsoon, Atmos. Chem. Phys., 16, 9129-9147, https://doi.org/10.5194/acp-16-9129-2016, 2016.

Bergman, J. W., Fierli, F., Jensen, E. J., Honomichl, S., and Pan, L. L.: Boundary layer sources for the Asian anticyclone: Regional contributions to a vertical conduit, J. Geophys. Res.-Atmos., 118, 2560-2575, https://doi.org/10.1002/jgrd.50142, 2013.

Boos, W. R. and Kuang, Z.: Dominant control of the South Asian monsoon by orographic insulation versus plateau heating, Nature, 463, 218-222, https://doi.org/10.1038/nature08707, 2010.

Boos, W. R. and Hurley, J. V.: Thermodynamic Bias in the Multimodel Mean Boreal Summer Monsoon, J. Climate, 26, 22792287, https://doi.org/10.1175/jcli-d-12-00493.1, 2013.

Brenninkmeijer, C. A. M., Crutzen, P., Boumard, F., Dauer, T., Dix, B., Ebinghaus, R., Filippi, D., Fischer, H., Franke, H., Frieß, U., Heintzenberg, J., Helleis, F., Hermann, M., Kock, H. H., Koep- pel, C., Lelieveld, J., Leuenberger, M., Martinsson, B. G., Miemczyk, S., Moret, H. P., Nguyen, H. N., Nyfeler, P., Oram, D., O'Sullivan, D., Penkett, S., Platt, U., Pupek, M., Ramonet, M., Randa, B., Reichelt, M., Rhee, T. S., Rohwer, J., Rosenfeld, K., Scharffe, D., Schlager, H., Schumann, U., Slemr, F., Sprung, D., Stock, P., Thaler, R., Valentino, F., van Velthoven, P., Waibel, A., Wandel, A., Waschitschek, K., Wiedensohler, A., Xueref-Remy, I., Zahn, A., Zech, U., and Ziereis, H.: Civil Aircraft for the regular investigation of the atmosphere based on an instrumented container: The new CARIBIC system, Atmos. Chem. Phys., 7 , 4953-4976, https://doi.org/10.5194/acp-7-4953-2007, 2007.

Cecil, D. J.: LIS/OTD 2.5 Degree Low Resolution Monthly Climatology Time Series (LRMTS): Data set available online from the NASA Global Hydrology Resource Center DAAC, Huntsville, Alabama, USA, https://doi.org/10.5067/LIS/LISOTD/DATA311 (last access: 18 September 2017), 2006.

Cristofanelli, P., Bracci, A., Sprenger, M., Marinoni, A., Bonafè, U., Calzolari, F., Duchi, R., Laj, P., Pichon, J. M., Roccato, F., Venzac, H., Vuillermoz, E., and Bonasoni, P.: Tropospheric ozone variations at the Nepal Climate ObservatoryPyramid (Himalayas, $5079 \mathrm{~m}$ a.s.l.) and influence of deep stratospheric intrusion events, Atmos. Chem. Phys., 10, 6537-6549, https://doi.org/10.5194/acp-10-6537-2010, 2010.

Crutzen, P. J. and Schmailzl, U.: Chemical budgets of the stratosphere, Planet. Space Sci., 31, 1009-1032, 1983.

Deckert, R., Jöckel, P., Grewe, V., Gottschaldt, K.-D., and Hoor, P.: A quasi chemistry-transport model mode for EMAC, Geosci Model Dev., 4, 195-206, https://doi.org/10.5194/gmd-4-1952011, 2011.

Dee, D. P., Uppala, S. M., Simmons, A. J., Berrisford, P., Poli, P., Kobayashi, S., Andrae, U., Balmaseda, M. A., Balsamo, G., Bauer, P., Bechtold, P., Beljaars, A. C. M., van de Berg, L., Bidlot, J., Bormann, N., Delsol, C., Dragani, R., Fuentes, M., Geer, A. J., Haimberger, L., Healy, S. B., Hersbach, H., Hólm, E. V., Isaksen, L., Kållberg, P., Köhler, M., Matricardi, M., McNally, A. P., Monge-Sanz, B. M., Morcrette, J. J., Park, B. K., Peubey, C., de Rosnay, P., Tavolato, C., Thépaut, J. N., and Vitart, F.: The ERA-Interim reanalysis: configuration and performance of the data assimilation system, Q. J. Roy. Meteor. Soc., 137, 553-597, https://doi.org/10.1002/qj.828, 2011.

Dethof, A., O’Neill, A., Slingo, J. M., and Smit, H. G. J.: A mechanism for moistening the lower stratosphere involving the Asian summer monsoon, Q. J. Roy. Meteor. Soc., 125, 1079-1106, https://doi.org/10.1002/qj.1999.49712555602, 1999.

Draxler, R. R. and Hess, G. D.: An overview of the HYSPLIT_4 modelling system for trajectories, dispersion and deposition, Aust. Meteorol. Mag., 47, 295-308, 1998.

Draxler, R. R. and Rolph, G.: HYSPLIT (HYbrid SingleParticleLagrangian Integrated Trajectory) model, available at: http://www.arl.noaa.gov/ready/hysplit4.html, last access: 26 June 2015.

Dunkerton, T. J.: Evidence of meridional motion in the summer lower stratosphere adjacent to monsoon regions, J. Geophys Res., 100, 16675-16688, https://doi.org/10.1029/95JD01263, 1995.

Ehhalt, D. H. and Rohrer, F.: The impact of commercial aircraft on tropospheric ozone, Proceedings of the 7th BOC Priestley Conference, Lewisburg, Pennsylvania, USA, 24-27 June 1994, 1994. 
Fischer, H., Wienhold, F. G., Hoor, P., Bujok, O., Schiller, C., Siegmund, P., Ambaum, M., Scheeren, H. A., and Lelieveld, J.: Tracer correlations in the northern high latitude lowermost stratosphere: Influence of cross-tropopause mass exchange, Geophys. Res. Lett., 27, 97-100, https://doi.org/10.1029/1999gl010879, 2000.

Flohn, H.: Recent investigation on the mechanism of the "summer monsoon" of southern and eastern Asia, in: Proc. Symp. Monsoon of the World, New Delhi, 19-21 February 1958, 75-88, 1960.

Fu, R., Hu, Y., Wright, J. S., Jiang, J. H., Dickinson, R. E., Chen, M., Filipiak, M., Read, W. G., Waters, J. W., and $\mathrm{Wu}, \mathrm{D}$. L.: Short circuit of water vapor and polluted air to the global stratosphere by convective transport over the Tibetan Plateau, P. Natl. Acad. Sci. USA, 103, 5664-5669, https://doi.org/10.1073/pnas.0601584103, 2006.

Garny, H. and Randel, W. J.: Dynamic variability of the Asian monsoon anticyclone observed in potential vorticity and correlations with tracer distributions, J. Geophys. Res.-Atmos., 118, 1342113433, https://doi.org/10.1002/2013jd020908, 2013.

Garny, H. and Randel, W. J.: Transport pathways from the Asian monsoon anticyclone to the stratosphere, Atmos. Chem. Phys., 16, 2703-2718, https://doi.org/10.5194/acp-16-27032016, 2016.

Gettelman, A., Hoor, P., Pan, L. L., Randel, W. J., Hegglin, M. I., and Birner, T.: The Extratropical Upper Troposphere and Lower Stratosphere, Rev. Geophys., 49, RG3003, https://doi.org/10.1029/2011rg000355, 2011.

Goswami, B. N.: South Asian monsoon, in: Intraseasonal Variability in the Atmosphere-Ocean Climate System, 2nd ed., edited by: Lau, W. K. M. and Waliser, D. E., Springer-Verlag, Berlin, Heidelberg, Germany, 21-72, 2012.

Gottschaldt, K., Voigt, C., Jöckel, P., Righi, M., Deckert, R., and Dietmüller, S.: Global sensitivity of aviation $\mathrm{NO}_{x}$ effects to the $\mathrm{HNO}_{3}$-forming channel of the $\mathrm{HO}_{2}+\mathrm{NO}$ reaction, Atmos. Chem. Phys., 13, 3003-3025, https://doi.org/10.5194/acp-133003-2013, 2013.

Gottschaldt, K.-D., Schlager, H., Baumann, R., Bozem, H., Eyring, V., Hoor, P., Jöckel, P., Jurkat, T., Voigt, C., Zahn, A., and Ziereis, H.: Trace gas composition in the Asian summer monsoon anticyclone: a case study based on aircraft observations and model simulations, Atmos. Chem. Phys., 17, 6091-6111, https://doi.org/10.5194/acp-17-6091-2017, 2017.

Grewe, V., Brunner, D., Dameris, M., Grenfell, J. L., Hein, R., Shindell, D., and Staehelin, J.: Origin and variability of upper tropospheric nitrogen oxides and ozone at northern mid-latitudes, Atmos. Environ., 35, 3421-3433, 2001.

Grewe, V.: Impact of Lightning on Air Chemistry and Climate, in: Lightning: Principles, Instruments and Applications, edited by: Betz, H. D., Schumann, U., and Laroche, P., Springer Science+Business Media B. V., Dordrecht, 537-549, 2009.

Grewe, V., Tsati, E., Mertens, M., Frömming, C., and Jöckel, P.: Contribution of emissions to concentrations: the TAGGING 1.0 submodel based on the Modular Earth Submodel System (MESSy 2.52), Geosci. Model Dev., 10, 2615-2633, https://doi.org/10.5194/gmd-10-2615-2017, 2017.

Grooß, J. U., Brühl, C., and Peter, T.: Impact of aircraft emissions on tropospheric and stratospheric ozone. Part 1: Chemistry and 2-d model results, Atmos. Environ., 32, 3171-3184, 1998.
HALO database: https://halo-db.pa.op.dlr.de, last access: 9 April 2018.

Holton, J. R., Haynes, P. H., McIntyre, M. E., Douglass, A. R., Rood, R. B., and Pfister, L.: Stratospheretroposphere exchange, Rev. Geophys., 33, 403-439, https://doi.org/10.1029/95RG02097, 1995.

Hoor, P., Fischer, H., Lange, L., Lelieveld, J., and Brunner, D.: Seasonal variations of a mixing layer in the lowermost stratosphere as identified by the $\mathrm{CO}-\mathrm{O}_{3}$ correlation from in situ measurements, J. Geophys. Res., 107, 4044, https://doi.org/10.1029/2000jd000289, 2002.

Hoor, P., Gurk, C., Brunner, D., Hegglin, M. I., Wernli, H., and Fischer, H.: Seasonality and extent of extratropical TST derived from in-situ CO measurements during SPURT, Atmos. Chem. Phys., 4, 1427-1442, https://doi.org/10.5194/acp-4-1427-2004, 2004.

Hsu, C. J. and Plumb, R. A.: Nonaxisymmetric Thermally Driven Circulations and Upper-Tropospheric Monsoon Dynamics, J. Atmos. Sci., 57, 1255-1276, https://doi.org/10.1175/15200469(2000)057<1255:NTDCAU>2.0.CO;2, 2001.

IPCC: Climate Change 2013: The Physical Science Basis. Contribution of Working Group I to the Fifth Assessment Report of the Intergovernmental Panel on Climate Change, edited by: Stocker, T. F., Qin, D., Plattner, G.-K., Tignor, M., Allen, S. K., Boschung, J., Nauels, A., Xia, Y., Bex, V., and Midgley, P. M., Cambridge University Press, Cambridge, UK and New York, NY, USA,, 1535 pp., 2013.

Jaeglé, L., Jacob, D. J., Brune, W. H., Tan, D., Faloona, I. C., Weinheimer, A. J., Ridley, B. A., Campos, T. L., and Sachse, G. W.: Sources of HOxand production of ozone in the upper troposphere over the United States, Geophys. Res. Lett., 25, 17091712, https://doi.org/10.1029/98g100041, 1998.

Jöckel, P., Tost, H., Pozzer, A., Brühl, C., Buchholz, J., Ganzeveld, L., Hoor, P., Kerkweg, A., Lawrence, M. G., Sander, R., Steil, B., Stiller, G., Tanarhte, M., Taraborrelli, D., van Aardenne, J., and Lelieveld, J.: The atmospheric chemistry general circulation model ECHAM5/MESSy1: consistent simulation of ozone from the surface to the mesosphere, Atmos. Chem. Phys., 6, 50675104, https://doi.org/10.5194/acp-6-5067-2006, 2006.

Jöckel, P., Kerkweg, A., Pozzer, A., Sander, R., Tost, H., Riede, H., Baumgaertner, A., Gromov, S., and Kern, B.: Development cycle 2 of the Modular Earth Submodel System (MESSy2), Geosci. Model Dev., 3, 717-752, https://doi.org/10.5194/gmd-3717-2010, 2010.

Jöckel, P., Tost, H., Pozzer, A., Kunze, M., Kirner, O., Brenninkmeijer, C. A. M., Brinkop, S., Cai, D. S., Dyroff, C., Eckstein, J., Frank, F., Garny, H., Gottschaldt, K.-D., Graf, P., Grewe, V., Kerkweg, A., Kern, B., Matthes, S., Mertens, M., Meul, S., Neumaier, M., Nützel, M., Oberländer-Hayn, S., Ruhnke, R., Runde, T., Sander, R., Scharffe, D., and Zahn, A.: Earth System Chemistry integrated Modelling (ESCiMo) with the Modular Earth Submodel System (MESSy) version 2.51, Geosci. Model Dev., 9, 1153-1200, https://doi.org/10.5194/gmd-9-1153-2016, 2016.

Jurkat, T., Voigt, C., Kaufmann, S., Zahn, A., Sprenger, M., Hoor, P., Bozem, H., Müller, S., Dörnbrack, A., Schlager, H., Bönisch, H., and Engel, A.: A quantitative analysis of stratospheric $\mathrm{HCl}, \mathrm{HNO}_{3}$, and $\mathrm{O}_{3}$ in the tropopause region near the subtropical jet, Geophys. Res. Lett., 41, 3315-3321, https://doi.org/10.1002/2013g1059159, 2014. 
Jurkat, T., Kaufmann, S., Voigt, C., Schäuble, D., Jeßberger, P., and Ziereis, H.: The airborne mass spectrometer AIMS Part 2: Measurements of trace gases with stratospheric or tropospheric origin in the UTLS, Atmos. Meas. Tech., 9, 1907-1923, https://doi.org/10.5194/amt-9-1907-2016, 2016.

Konopka, P., Grooß, J.-U., Günther, G., Ploeger, F., Pommrich, R., Müller, R., and Livesey, N.: Annual cycle of ozone at and above the tropical tropopause: observations versus simulations with the Chemical Lagrangian Model of the Stratosphere (CLaMS), Atmos. Chem. Phys., 10, 121-132, https://doi.org/10.5194/acp-10121-2010, 2010.

Kunz, A., Sprenger, M., and Wernli, H.: Climatology of potential vorticity streamers and associated isentropic transport pathways across PV gradient barriers, J. Geophys. Res.-Atmos., 120, 3802-3821, https://doi.org/10.1002/2014jd022615, 2015.

Kunze, M., Braesicke, P., Langematz, U., Stiller, G., Bekki, S., Brühl, C., Chipperfield, M., Dameris, M., Garcia, R., and Giorgetta, M.: Influences of the Indian Summer Monsoon on Water Vapor and Ozone Concentrations in the UTLS as Simulated by Chemistry-Climate Models, J. Climate, 23, 3525-3544, https://doi.org/10.1175/2010jcli3280.1, 2010.

Lawrence, M. G. and Lelieveld, J.: Atmospheric pollutant outflow from southern Asia: a review, Atmos. Chem. Phys., 10, 1101711096, https://doi.org/10.5194/acp-10-11017-2010, 2010.

Lelieveld, J., Crutzen, P. J., Ramanathan, V., Andreae, M. O., Brenninkmeijer, C. A. M., Campos, T., Cass, G. R., Dickerson, R. R., Fischer, H., de Gouw, J. A., Hansel, A., Jefferson, A., Kley, D., de Laat, A. T. J., Lal, S., Lawrence, M. G., Lobert, J. M., Mayol-Bracero, O. L., Mitra, A. P., Novakov, T., Oltmans, S. J., Prather, K. A., Reiner, T., Rodhe, H., Scheeren, H. A., Sikka, D., and Williams, J.: The Indian Ocean Experiment: Widespread Air Pollution from South and Southeast Asia, Science, 291, 10311036, https://doi.org/10.1126/science.1057103, 2001.

Lelieveld, J., Berresheim, H., Borrmann, S., Crutzen, P. J., Dentener, F. J., Fischer, H., Feichter, J., Flatau, P. J., Heland, J., Holzinger, R., Korrmann, R., Lawrence, M. G., Levin, Z., Markowicz, K. M., Mihalopoulos, N., Minikin, A., Ramanathan, V., de Reus, M., Roelofs, G. J., Scheeren, H. A., Sciare, J., Schlager, H., Schultz, M., Siegmund, P., Steil, B., Stephanou, E. G., Stier, P., Traub, M., Warneke, C., Williams, J., and Ziereis, H.: Global Air Pollution Crossroads over the Mediterranean, Science, 298, 794-799, https://doi.org/10.1126/science.1075457, 2002.

Lelieveld, J., Hoor, P., Jöckel, P., Pozzer, A., Hadjinicolaou, P., Cammas, J.-P., and Beirle, S.: Severe ozone air pollution in the Persian Gulf region, Atmos. Chem. Phys., 9, 1393-1406, https://doi.org/10.5194/acp-9-1393-2009, 2009.

Li, Q., Jacob, D. J., Logan, J. A., Bey, I., Yantosca, R. M., Liu, H., Martin, R. V., Fiore, A. M., Field, B. D., Duncan, B. N., and Thouret, V.: A Tropospheric Ozone Maximum Over the Middle East, Geophys. Res. Lett., 28, 3235-3238, https://doi.org/10.1029/2001GL013134, 2001.

Li, Q., Jiang, J. H., Wu, D. L., Read, W. G., Livesey, N. J., Waters, J. W., Zhang, Y., Wang, B., Filipiak, M. J., Davis, C. P., Turquety, S., Wu, S., Park, R. J., Yantosca, R. M., and Jacob, D. J.: Convective outflow of South Asian pollution: A global CTM simulation compared with EOS MLS observations, Geophys. Res. Lett., 32, L14826, https://doi.org/10.1029/2005gl022762, 2005.
Lin, J.-L., Weickman, K. M., Kiladis, G. N., Mapes, B. E., Schubert, S. D., Suarez, M. J., Bacmeister, J. T., and Lee, M.-I.: Subseasonal Variability Associated with Asian Summer Monsoon Simulated by 14 IPCC AR4 Coupled GCMs, J. Climate, 21, 45414567, https://doi.org/10.1175/2008jcli1816.1, 2008.

Liu, J. J., Jones, D. B. A., Worden, J. R., Noone, D., Parrington, M., and Kar, J.: Analysis of the summertime buildup of tropospheric ozone abundances over the Middle East and North Africa as observed by the Tropospheric Emission Spectrometer instrument, J. Geophys. Res., 114, D05304, https://doi.org/10.1029/2008jd010993, 2009.

Liu, J. J., Jones, D. B. A., Zhang, S., and Kar, J.: Influence of interannual variations in transport on summertime abundances of ozone over the Middle East, J. Geophys. Res., 116, D20310, https://doi.org/10.1029/2011jd016188, 2011.

Liu, Y., Wang, Y., Liu, X., Cai, Z., and Chance, K.: Tibetan middle tropospheric ozone minimum in June discovered from GOME observations, Geophys. Res. Lett., 36, L05814, https://doi.org/10.1029/2008gl037056, 2009.

Lopez, P.: A Lightning Parameterization for the ECMWF Integrated Forecasting System, Mon. Weather Rev., 144, 3057-3075, https://doi.org/10.1175/mwr-d-16-0026.1, 2016.

Lubis, S. W. and Nakamura, N.: Stratospheric Influence on Summer Monsoon and Associated Planetary Wave Breaking and Mixing in the Subtropical Tropopause Region, AGU Fall Meeting, A51N-05, 15 December 2017, New Orleans, LA, USA, 2017.

Marcy, T. P., Fahey, D. W., Gao, R. S., Popp, P. J., Richard, E. C., Thompson, T. L., Rosenlof, K. H., Ray, E. A., Salawitch, R. J., Atherton, C. S., Bergmann, D. J., Ridley, B. A., Weinheimer, A. J., Loewenstein, M., Weinstock, E. M., and Mahoney, M. J.: Quantifying Stratospheric Ozone in the Upper Troposphere with in Situ Measurements of $\mathrm{HCl}$, Science, 304, 261265, https://doi.org/10.1126/science.1093418, 2004.

Müller, S., Hoor, P., Bozem, H., Gute, E., Vogel, B., Zahn, A., Bönisch, H., Keber, T., Krämer, M., Rolf, C., Riese, M., Schlager, H., and Engel, A.: Impact of the Asian monsoon on the extratropical lower stratosphere: trace gas observations during TACTS over Europe 2012, Atmos. Chem. Phys., 16, 10573-10589, https://doi.org/10.5194/acp-16-10573-2016, 2016.

Nützel, M., Dameris, M., and Garny, H.: Movement, drivers and bimodality of the South Asian High, Atmos. Chem. Phys., 16, 14755-14774, https://doi.org/10.5194/acp-16-14755-2016, 2016.

Pan, L. L., Randel, W. J., Gary, B. L., Mahoney, M. J., and Hintsa, E. J.: Definitions and sharpness of the extratropical tropopause: A trace gas perspective, J. Geophys. Res.-Atmos., 109, D23103, https://doi.org/10.1029/2004jd004982, 2004.

Pan, L. L., Honomichl, S. B., Kinnison, D., Abalos, M., Randel, W. J., Bergman, J. W., and Bian, J.: Transport of chemical tracers from the boundary layer to stratosphere associated with the dynamics of the Asian summer monsoon, J. Geophys. Res.-Atmos., 121, 1-16, https://doi.org/10.1002/2016JD025616, 2016.

Park, M., Randel, W. J., Emmons, L. K., Bernath, P. F., Walker, K. A., and Boone, C. D.: Chemical isolation in the Asian monsoon anticyclone observed in Atmospheric Chemistry Experiment (ACE-FTS) data, Atmos. Chem. Phys., 8, 757-764, https://doi.org/10.5194/acp-8-757-2008, 2008.

Park, M., Randel, W. J., Emmons, L. K., and Livesey, N. J.: Transport pathways of carbon monoxide in the Asian sum- 
mer monsoon diagnosed from Model of Ozone and Related Tracers (MOZART), J. Geophys. Res., 114, D08303, https://doi.org/10.1029/2008jd010621, 2009.

Ploeger, F., Gottschling, C., Griessbach, S., Grooß, J.-U., Guenther, G., Konopka, P., Müller, R., Riese, M., Stroh, F., Tao, M., Ungermann, J., Vogel, B., and von Hobe, M.: A potential vorticitybased determination of the transport barrier in the Asian summer monsoon anticyclone, Atmos. Chem. Phys., 15, 13145-13159, https://doi.org/10.5194/acp-15-13145-2015, 2015.

Pokhrel, S., Chaudhari, H. S., Saha, S. K., Dhakate, A., Yadav, R. K., Salunke, K., Mahapatra, S., and Rao, S. A.: ENSO, IOD and Indian Summer Monsoon in NCEP climate forecast system, Clim. Dynam., 39, 2143-2165, https://doi.org/10.1007/s00382012-1349-5, 2012.

Popovic, J. M. and Plumb, R. A.: Eddy Shedding from the Upper-Tropospheric Asian Monsoon Anticyclone, J. Atmos. Sci., 58, 93-104, https://doi.org/10.1175/15200469(2001)058<0093:ESFTUT>2.0.CO;2, 2001.

Randel, W. J. and Park, M.: Deep convective influence on the Asian summer monsoon anticyclone and associated tracer variability observed with Atmospheric Infrared Sounder (AIRS), J. Geophys. Res., 111, D12314, https://doi.org/10.1029/2005jd006490, 2006.

Randel, W. J., Pan, L. L., and Bian, J.: Workshop on dynamics, transport and chemistry of the UTLS Asian Monsoon, Adv. Atmos. Sci., 33, 1096-1098, https://doi.org/10.1007/s00376-0166169-9, 2016.

Rauthe-Schöch, A., Baker, A. K., Schuck, T. J., Brenninkmeijer, C. A. M., Zahn, A., Hermann, M., Stratmann, G., Ziereis, H., van Velthoven, P. F. J., and Lelieveld, J.: Trapping, chemistry, and export of trace gases in the South Asian summer monsoon observed during CARIBIC flights in 2008, Atmos. Chem. Phys., 16, 36093629, https://doi.org/10.5194/acp-16-3609-2016, 2016.

re3data.org: HALO database; editing status 2018-02-07; re3data.org - Registry of Research Data Repositories, https://doi.org/10.17616/R39Q0T, last access: 28 March 2018.

Ren, R., Wu, G., Cai, M., Sun, S., Liu, X., and Li, W.: Progress in Research of Stratosphere-Troposphere Interactions: Application of Isentropic Potential Vorticity Dynamics and the Effects of the Tibetan Plateau, J. Meteor. Res., 28, 714-731, https://doi.org/10.1007/s13351-014-4026-2, 2014.

Richards, N. A. D., Arnold, S. R., Chipperfield, M. P., Miles, G., Rap, A., Siddans, R., Monks, S. A., and Hollaway, M. J.: The Mediterranean summertime ozone maximum: global emission sensitivities and radiative impacts, Atmos. Chem. Phys., 13, 2331-2345, https://doi.org/10.5194/acp-13-2331-2013, 2013.

Rodwell, M. J. and Hoskins, B. A.: Monsoons and the dynamics of deserts, Q. J. Roy. Meteor. Soc., 122, 1385-1404, https://doi.org/10.1002/qj.49712253408, 1996.

Safieddine, S., Boynard, A., Hao, N., Huang, F., Wang, L., Ji, D., Barret, B., Ghude, S. D., Coheur, P.-F., Hurtmans, D., and Clerbaux, C.: Tropospheric ozone variability during the East Asian summer monsoon as observed by satellite (IASI), aircraft (MOZAIC) and ground stations, Atmos. Chem. Phys., 16, 10489-10500, https://doi.org/10.5194/acp-16-10489-2016, 2016.

Santee, M. L., Manney, G. L., Livesey, N. J., Schwartz, M. J., Neu, J. L., and Read, W. G.: A comprehensive overview of the climatological composition of the Asian summer monsoon anticyclone based on 10 years of Aura Microwave Limb Sounder measurements, J. Geophys. Res.-Atmos., 122, 54915514, https://doi.org/10.1002/2016jd026408, 2017.

Scheeren, H. A., Lelieveld, J., Roelofs, G. J., Williams, J., Fischer, H., de Reus, M., de Gouw, J. A., Warneke, C., Holzinger, R., Schlager, H., Klüpfel, T., Bolder, M., van der Veen, C., and Lawrence, M.: The impact of monsoon outflow from India and Southeast Asia in the upper troposphere over the eastern Mediterranean, Atmos. Chem. Phys., 3, 1589-1608, https://doi.org/10.5194/acp-3-1589-2003, 2003.

Schiller, C. L., Bozem, H., Gurk, C., Parchatka, U., Königstedt, R., Harris, G. W., Lelieveld, J., and Fischer, H.: Applications of quantum cascade lasers for sensitive trace gas measurements of $\mathrm{CO}, \mathrm{CH} 4, \mathrm{~N} 2 \mathrm{O}$ and $\mathrm{HCHO}$, App. Phys. B, 92, 419-430, https://doi.org/10.1007/s00340-008-3125-0, 2008.

Schuck, T. J., Brenninkmeijer, C. A. M., Baker, A. K., Slemr, F., von Velthoven, P. F. J., and Zahn, A.: Greenhouse gas relationships in the Indian summer monsoon plume measured by the CARIBIC passenger aircraft, Atmos. Chem. Phys., 10, 39653984, https://doi.org/10.5194/acp-10-3965-2010, 2010.

Schumann, U. and Huntrieser, H.: The global lightning-induced nitrogen oxides source, Atmos. Chem. Phys., 7, 3823-3907, https://doi.org/10.5194/acp-7-3823-2007, 2007.

Seinfeld, J. H. and Pandis, S. N.: Relative roles of VOC and $\mathrm{NO}_{x}$ in ozone formation, in: Atmospheric Chemistry and Physics, John Wiley \& Sons, New York, 209-303, 1998.

Seinfeld, J. H. and Pandis, S. N.: Atmospheric chemistry and physics: from air pollution to climate change, 2nd edition ed., John Wiley \& Sons, Inc., Hoboken, New Jersey, 151-154 and 224-225, 2006.

Sprung, D. and Zahn, A.: Acetone in the upper troposphere/lowermost stratosphere measured by the CARIBIC passenger aircraft: Distribution, seasonal cycle, and variability, J. Geophys. Res., 115, D16301, https://doi.org/10.1029/2009jd012099, 2010.

Stratmann, G., Ziereis, H., Stock, P., Brenninkmeijer, C. A. M., Zahn, A., Rauthe-Schöch, A., Velthoven, P. V., Schlager, H., and Volz-Thomas, A.: $\mathrm{NO}$ and $\mathrm{NO}_{y}$ in the upper troposphere: Nine years of CARIBIC measurements onboard a passenger aircraft, Atmos. Environ., 133, 93-111, https://doi.org/10.1016/j.atmosenv.2016.02.035, 2016.

Tiedtke, M.: A comprehensive mass flux scheme for cumulus parameterization in large-scale models, Mon. Weather Rev., 117, 1179-1800, 1989.

Tost, H.: Global Modelling of Cloud, Convection and Precipitation Influences on Trace Gases and Aerosols, PhD, University Bonn, Bonn, 2006.

Tost, H., Jöckel, P., and Lelieveld, J.: Lightning and convection parameterisations - uncertainties in global modelling, Atmos. Chem. Phys., 7, 4553-4568, 2007.

Tyrlis, E., Škerlak, B., Sprenger, M., Wernli, H., Zittis, G., and Lelieveld, J.: On the linkage between the Asian summer monsoon and tropopause fold activity over the eastern Mediterranean and the Middle East, J. Geophys. Res.-Atmos., 119, 3202-3221, https://doi.org/10.1002/2013jd021113, 2014.

UCAR/NCAR/CISL/TDD: The NCAR Command Language (Version 6.3.0) (Software), Boulder, Colorado, USA, https://doi.org/10.5065/D6WD3XH5, 2017. 
Vogel, B., Günther, G., Müller, R., Grooß, J. U., Hoor, P., Krämer, M., Müller, S., Zahn, A., and Riese, M.: Fast transport from Southeast Asia boundary layer sources to northern Europe: rapid uplift in typhoons and eastward eddy shedding of the Asian monsoon anticyclone, Atmos. Chem. Phys., 14, 12745-12762, https://doi.org/10.5194/acp-14-12745-2014, 2014.

Voigt, C., Jessberger, P., Jurkat, T., Kaufmann, S., Baumann, R., Schlager, H., Bobrowski, N., Giuffrida, G., and Salerno, G.: Evolution of $\mathrm{CO}_{2}, \mathrm{SO}_{2}, \mathrm{HCl}$, and $\mathrm{HNO}_{3}$ in the volcanic plumes from Etna, Geophys. Res. Lett., 41, 2196-2203, https://doi.org/10.1002/2013GL058974, 2014.

Yan, R.-C., Bian, J.-C., and Fan, Q.-J.: The Impact of the South Asia High Bimodality on the Chemical Composition of the Upper Troposphere and Lower Stratosphere, Atmos. Ocean. Sci. Lett., 4, 229-234, 2011.
Zahn, A., Weppner, J., Widmann, H., Schlote-Holubek, K., Burger, B., Kühner, T., and Franke, H.: A fast and precise chemiluminescence ozone detector for eddy flux and airborne application, Atmos. Meas. Tech., 5, 363-375, https://doi.org/10.5194/amt-5363-2012, 2012.

Ziereis, H., Schlager, H., and Schulte, P.: Distributions of NO, $\mathrm{NO}_{x}$, and $\mathrm{NO}_{y}$ in the upper troposphere and lower stratosphere between $28^{\circ}$ and $61^{\circ} \mathrm{N}$ during POLINAT 2, J. Geophys. Res., 105, 3653-3664, https://doi.org/10.1029/1999JD900870, 2000. 